\title{
Utilization of Tires Waste-Derived Magnetic-Activated Carbon for the Removal of Hexavalent Chromium from Wastewater
}

\author{
Waqas Ahmad ${ }^{1}$, Shanif Qaiser ${ }^{1}$, Rahman Ullah ${ }^{1}$, Badrul Mohamed Jan ${ }^{2}$, Michael A. Karakassides ${ }^{3} \mathbb{D}$, \\ Constantinos E. Salmas ${ }^{3}$ (D), George Kenanakis ${ }^{4}$ (D) and Rabia Ikram ${ }^{2, *}$ \\ 1 Institute of Chemical Sciences, University of Peshawar, Peshawar 25120, Pakistan; \\ waqasahmad@uop.edu.pk (W.A.); shanifqaisar888@gmail.com (S.Q.); rahmandawar@uop.edu.pk (R.U.) \\ 2 Department of Chemical Engineering, University of Malaya, Kuala Lumpur 50603, Malaysia; \\ badrules@um.edu.my \\ 3 Department of Materials Science and Engineering, University of Ioannina, GR-45110 Ioannina, Greece; \\ mkarakas@uoi.gr (M.A.K.); ksalmas@uoi.gr (C.E.S.) \\ 4 Institute of Electronic Structure and Laser, Foundation for Research and Technology-Hellas, N. Plastira 100, \\ Vasilika Vouton, GR-70013 Heraklion, Crete, Greece; gkenanak@iesl.forth.gr \\ * Correspondence: raab@um.edu.my
}

check for

updates

Citation: Ahmad, W.; Qaiser, S.;

Ullah, R.; Mohamed Jan, B.;

Karakassides, M.A.; Salmas, C.E.;

Kenanakis, G.; Ikram, R. Utilization

of Tires Waste-Derived

Magnetic-Activated Carbon for the Removal of Hexavalent Chromium from Wastewater. Materials 2021, 14, 34. https://dx.doi.org/10.3390/ ma14010034

Received: 23 November 2020 Accepted: 19 December 2020 Published: 23 December 2020

Publisher's Note: MDPI stays neutral with regard to jurisdictional claims in published maps and institutional affiliations.

Copyright: () 2020 by the authors. Licensee MDPI, Basel, Switzerland. This article is an open access article distributed under the terms and conditions of the Creative Commons Attribution (CC BY) license (https: / / creativecommons.org/ licenses/by/4.0/).

\begin{abstract}
The present study focuses on fabrication of magnetic activated carbon (M-AC) using tire waste and its potential investigation for adsorption of $\mathrm{Cr}$ (VI) from wastewater. The composite material (M-AC) was synthesized by pyrolysis followed by in situ magnetization method, and characterized by FTIR, FESEM, EDX, and XRD analysis. The maximum adsorption of Cr (VI) ion over composite adsorbent was found ( 99.5\%) to occur at $\mathrm{pH} 2$, sample volume $10 \mathrm{~mL}$, adsorbent dose $100 \mathrm{mg}$, contact time $30 \mathrm{~min}$. The adsorption process was endothermic, feasible, spontaneous, and was found to follow pseudo second order of the reaction. The $\mathrm{Cr}$ ion could be completely desorbed ( $\sim 99.3 \%$ ) from the composite adsorbent by using $20 \mathrm{~mL}$ of $2 \mathrm{M} \mathrm{NaOH}$ solution. The composite adsorbent was regenerated by continuous adsorption and desorption for 5 consecutive cycles by using $10 \mathrm{~mL} 0.1 \mathrm{M} \mathrm{HCl}$ solution. M-AC also performed well in case of tannery wastewater by removing about $97 \%$ of $\mathrm{Cr}(\mathrm{VI})$.
\end{abstract}

Keywords: tire waste; hexavalent chromium; magnetic activated carbon; wastewater treatment; tannery wastewater

\section{Introduction}

The spontaneous growth in global population as well as the advancement of industrial processes have been considered as the main source for the large accumulation of toxic metals in various water bodies [1]. In the past several years, large quantities of organic wastes such as pharmaceutical, food and beverages, textiles, pulp and paper, etc., from various industrial processes have been detected in tannery wastewaters [2,3]. Numerous methods such as precipitation, coagulation, filtration, bio-sorption, ion-exchange, adsorption, and stabilization have been utilized for $\mathrm{Cr}$ removal from wastewater [4-8]. Adsorption is currently the most widely used technique for the removal of heavy metals in a wide variety of wastewater matrices [9]. Nevertheless, a challenge therein is the development of an enhanced, cheap, and recoverable adsorbent that can effectively remove all types of the organic pollutants.

Environmentally, chromium (Cr) is one of the most widespread and threatening contaminants in wastewater [10]. Among significant heavy metals, $\mathrm{Cr}$ imparts a major role in water pollution as well as contamination of various nutritional plants [11]. The removal of $\mathrm{Cr}$ from wastewater has grasped the attention of the scientific community around the globe. To improve the environmental degradation, the presence of toxic $\mathrm{Cr}$ ions needs to be properly managed. The toxic effects of hexavalent chromium $(\mathrm{Cr}(\mathrm{VI}))$ have been observed through tanning, industrial dyes, mining, production of metals and alloys, corrosive paints, 
and electroplating [12,13]. As a dominant carcinogenic agent, $\mathrm{Cr}$ has caused hazardous effects through various cancerous diseases [14]. Adsorption has proven to be one of the promising methods to separate $\mathrm{Cr}(\mathrm{VI})$ from wastewater. However, selection of reliable adsorbents has made it crucial.

Researchers have shown reduction of $\mathrm{Cr}$ (VI) to $\mathrm{Cr}$ (III) using precipitation and coagulation [15]. Recent studies have reported novel mechanisms such as in situ deposition technique for the removal of heavy metals. The process involved deposition of electrodes to reduce $\mathrm{Cr}(\mathrm{VI})$ to $\mathrm{Cr}$ (III) inside the strip phase by incorporating iron and graphite rods as anodes [16,17].

Currently, an extensive research has been focused on the conversion of activated carbon (AC) from industrial wastes. This has led to the promotion of eco-friendly and costeffective effects to commercialize AC. Natural, polymeric, zeolite, and nano adsorbents are reported as efficient and commonly used as remediation of wastewater treatment $[18,19]$. The conversion of tire waste into carbonaceous materials is an excellent alternative to environmental pollution, as it is believed to have the ability to enhance the absorption of organic pollutants and improve the removal efficiency. Until now, a lot of studies concerning the dispersion of magnetic iron oxide nanoparticles into carbon porous matrices have been reported [20-23]. However, the preparation and utilization of $\mathrm{AC}$ and magnetic $\mathrm{AC}$ (M-AC) from tire waste for $\mathrm{Cr}$ removal has rarely been reported in the literature [24].

In the current study, $\mathrm{M}-\mathrm{AC}$ was synthesized from tire waste by acid demineralization and thermal pyrolysis at $450{ }^{\circ} \mathrm{C}$ followed by in situ magnetization. The prepared M-AC was characterized by FTIR, FESEM, EDX, and XRD analysis, and utilized as adsorbent for removal and recovery of $\mathrm{Cr}(\mathrm{VI})$ from tannery wastewater through batch mode adsorption. The adsorption parameters were optimized, and thermodynamics of adsorption was also investigated.

\section{Experimental Work}

\subsection{Chemicals and Reagents}

All chemicals used in this study were of analytical grade. Hydrochloric acid $(\mathrm{HCl})$, Sulphuric acid $\left(\mathrm{H}_{2} \mathrm{SO}_{4}\right)$ and Nitric acid $\left(\mathrm{HNO}_{3}\right)$, and anhydrous Potassium dichromate $\left(\mathrm{K}_{2} \mathrm{Cr}_{2} \mathrm{O}_{7}\right)$ were purchased from Merck KGaA, Darmstadt, Germany. Acetone $\left(\mathrm{CH}_{3} \mathrm{COCH}_{3}\right)$, Sodium hydroxide $(\mathrm{NaOH})$, and Methanol $\left(\mathrm{CH}_{3} \mathrm{OH}\right)$ were purchased from Sigma-Aldrich, St. Louis, MO, USA.

\subsection{Sample and Materials Collection}

Tanning wastewater containing $\mathrm{Cr}$ concentration $1640 \mathrm{mg} / \mathrm{L}$ was collected from Prime leather industries Pvt Ltd. (Sheikhopura, Punjab, Pakistan). The collected wastewater was stored in a plastic bottle, prewashed with diluted nitric acid, and immediately sent to the laboratory for determination of $\mathrm{Cr}$ concentration, removal, and recovery experiments.

To prepare activated carbon from the material, tire waste was collected from the local market (puncher shop) from Hayatabad Peshawar, Pakistan. The collected sample was washed with water several times to remove dust particles, and then dried in the oven at $60^{\circ} \mathrm{C}$ for the whole night.

\subsection{Preparation of Model Cr Solution}

For the preparation of model $\mathrm{Cr}$ solution, $0.25 \mathrm{~g}$ of potassium dichromate (SigmaAldrich, St. Louis, MO, USA) was dissolved in $500 \mathrm{~mL}$ of distilled water, to obtain a solution containing $500 \mathrm{ppm} \mathrm{Cr}(0.0016 \mathrm{~mol} / \mathrm{L})$.

\subsection{Preparation of the Adsorbent}

$\mathrm{M}-\mathrm{AC}$ was used for the adsorption and recovery of $\mathrm{Cr}(\mathrm{VI})$ ions. The stepwise synthesis and preparation of the adsorbent is given in details as below. 


\subsubsection{Preparation of Activated Carbon}

The collected tire waste was chopped with a paper cutter. For demineralization, the chopped tire waste $(20 \mathrm{~g})$ pieces were taken in a $100 \mathrm{~mL}$ beaker, and $30 \mathrm{~mL}$ of diluted nitric acid was added to it and allowed to digest for a few hours. After demineralization, the solid was separated from the mother liquid through filtration. The sample was washed with deionized water until it become neutral. The residue was dried in the oven at $60^{\circ} \mathrm{C}$.

The dried sample was heated in the tube furnace for pyrolysis. The tube used for the pyrolysis in the tube furnace was $14.7 \mathrm{~cm}$ in length and $2.54 \mathrm{~cm}$ in diameter. The tube was loaded from the sample, fitted in the tube furnace, and connected with inert gas $\left(\mathrm{N}_{2}\right)$. The sample was heated for $4 \mathrm{~h}$ at $450{ }^{\circ} \mathrm{C}$. After heating, the final sample was collected and stored for further study.

For activation, the sample $(1 \mathrm{~g})$ was ultrasonically dispersed in $100 \mathrm{~mL}$ conical flask. After the complete dispersion, $0.2 \mathrm{M}$ potassium hydroxide (KOH; Sigma-Aldrich, St. Louis, MO, USA) (30 mL) was added and stirred for $3 \mathrm{~h}$. The sample was separated from the liquid through Wattman filter paper, washed with distilled water till the washing was neutral, and then dried in the oven for $3 \mathrm{~h}$ at $60^{\circ} \mathrm{C}$.

\subsubsection{Magnetization of Activated Carbon}

M-AC was prepared by direct method as reported in the literature [25]. Activated carbon (AC) $1.0 \mathrm{~g}$ was ultrasonically dispersed in deionized water for two hours. About $3.0 \mathrm{~g}$ $\mathrm{FeCl}_{3}$ (Sigma-Aldrich, St. Louis, MO, USA) and $5.5 \mathrm{~g} \mathrm{FeSO}_{4}$ (Sigma-Aldrich, St. Louis, MO, USA) were added to the dispersion under continuous stirring, followed by addition of $10 \mathrm{~mL}$ of $\mathrm{NH}_{4} \mathrm{OH}$ (Sigma-Aldrich, St. Louis, MO, USA). A black precipitate was formed, which was separated from the suspension using an external magnet. The M-AC was excessively washed with distilled water and ethanol, and then dried under vacuum at $60^{\circ} \mathrm{C}$.

\subsection{Characterization of Adsorbent}

The tire waste-derived $\mathrm{AC}$ and M-AC was characterized by different instrumental analyses including FTIR, SEM, EDX, and XRD analysis. The FTIR analysis of the M-AC was carried out using an ATR-FTIR spectrophotometer (FTIR, PerkinElmer Spectrum 400, Amherst. MA, USA) equipped with an Attenuated Total Reflectance (ATR) diamond crystal plate and a pressure clamp; the spectra were collected at a resolution of $2 \mathrm{~cm}^{-1}$ and as the average of 50 scans over the spectral region $4000-500 \mathrm{~cm}^{-1}$. Surface morphology was examined through scanning electronic microscopy (SEM JSM 5910, JEOL, Japan). EDX analysis of the adsorbent was carried out by an EDX detector equipped with a SEM microscope. Structural parameters of the adsorbent were studied by a XRD analysis model (XPert ${ }^{3}$ Powder-Malvern Panalytical, Holland).

\subsection{Batch Adsorption Experiments}

For batch mode adsorption experiments, model $\mathrm{Cr}$ solution containing $500 \mathrm{mg} / \mathrm{L}$ $(0.0016 \mathrm{~mol} / \mathrm{L})$ of $\mathrm{Cr}(\mathrm{VI})$ was prepared. About $10 \mathrm{~mL}$ of model $\mathrm{Cr}$ solution was taken in a conical flask, and the $\mathrm{pH}$ of the sample was set to 2 by using $1 \mathrm{M}$ of $\mathrm{HCl}$ and $\mathrm{NaOH}$ solutions. About $100 \mathrm{mg}$ of AC or M-AC was added to the sample and agitated on a flask shaker for $40 \mathrm{~min}$. The adsorbent was separated from the sample with the help of an external magnet, and the sample was subjected to analyze $\mathrm{Cr}$ concentration. To achieve optimum conditions for adsorption, various parameters were optimized such as $\mathrm{pH}$, adsorbent dose, contact time, temperature, etc., to calculate maximum adsorption.

\subsection{Recovery of $\mathrm{Cr}$ from Adsorbent}

The spent M-AC adsorbent was added to $20 \mathrm{~mL}$ of $2 \mathrm{M}$ sodium hydroxide $(\mathrm{NaOH})$ and agitated for $40 \mathrm{~min}$ on the flask shaker. The magnetic adsorbent was collected from the solution with the help of an external magnet, and the solution was analyzed for determining the concentration of $\mathrm{Cr}$. The M-AC was then washed with deionized water, followed by 
diluted $\mathrm{HCl}$, and dried at $60{ }^{\circ} \mathrm{C}$, and the regenerated M-AC was ready for reuse in the next batch.

\subsection{Analysis of $\mathrm{Cr}$ in Water Sample}

The concentration of $\mathrm{Cr}$ was analyzed in waster sample through UV spectrophotometer (Shimadzu A90 UV-visible spectrophotometer; Shimadzu, Kyoto, Japan) using DPC method [26]. Diphenyl carbazide (DPC; Sigma-Aldrich, St. Louis, MO, USA) solution was prepared by dissolving $0.25 \mathrm{~g}$ DPC in $50 \mathrm{~mL}$ of acetone, which is used for complexation of $\mathrm{Cr}$ ions in this method. Standard solutions with different concentrations of $\mathrm{Cr}$, i.e., 50 , $75,100,150,200$, and $250 \mathrm{ppm}$ were prepared for construction of calibration curve. About $10 \mathrm{~mL}$ of the standard solution was taken in a $50 \mathrm{~mL}$ beaker, and $1 \mathrm{~mL}$ of DPC solution was added to the standard solution, and its absorbance was determined at $543 \mathrm{~nm}$. Likewise, the absorbance of the sample was also recorded, and the concentration of the $\mathrm{Cr}$ was determined from the calibration curve.

\subsection{Calculations}

The amount of $\mathrm{Cr}(\mathrm{VI})$ removed during the adsorption process was represented as \% adsorption, which was calculated from the initial $\mathrm{Cr}$ concentration in sample $\left(\mathrm{C}_{\mathrm{i}}\right)$, and concentration after adsorption $\left(\mathrm{C}_{\mathrm{f}}\right)$ in $\mathrm{mg} / \mathrm{L}$, using the following relation.

$$
\% \text { Absorption }=\frac{C_{i}-C_{f}}{C_{i}} \times 100
$$

Similarly, the adsorption capacity at equilibrium $\left(\mathrm{q}_{\mathrm{e}}\right)$ was calculated using values of $\mathrm{C}_{\mathrm{i}}, \mathrm{C}_{\mathrm{f}}$, volume of sample $(\mathrm{V})$, and mass of M-AC (m) through the following relation.

$$
\mathrm{qe}=\frac{\left(\mathrm{C}_{\mathrm{i}}-\mathrm{C}_{\mathrm{f}}\right) \times \mathrm{V}}{\mathrm{m}}
$$

Most commonly, the pseudo 1st and pseudo 2nd order kinetic models and intraparticle diffusion models are applied in the following mathematical forms $[27,28]$.

$$
\begin{aligned}
\frac{\mathrm{dq}}{\mathrm{dt}} & =\mathrm{K}_{1}\left(\mathrm{q}_{\mathrm{e}}-\mathrm{q}_{\mathrm{t}}\right) \\
\frac{\mathrm{t}}{\mathrm{q}_{\mathrm{t}}} & =\frac{\mathrm{t}}{\mathrm{q}_{\mathrm{e}}}+\frac{1}{\mathrm{k}_{2} \mathrm{q}_{\mathrm{e}}^{2}} \\
\mathrm{q}_{\mathrm{t}} & =\mathrm{K}_{1} \mathrm{t}^{1 / 2}+\mathrm{C}
\end{aligned}
$$

In these equations, $\mathrm{q}_{\mathrm{t}}$ is the adsorption capacity at any time " $\mathrm{t}$ " in $\mathrm{mg} \cdot \mathrm{g}^{-1}$, and $\mathrm{q}_{\mathrm{e}}$ is the adsorption capacity at equilibrium in $\mathrm{mg} \cdot \mathrm{g}^{-1}$. Whereas, $k_{1}\left(\mathrm{~h}^{-1}\right)$ is the pseudo $1 \mathrm{st}$ order rate constant, which is determined from the slope of the plot of "ln $\left(\mathrm{q}_{\mathrm{e}}-\mathrm{q}_{\mathrm{t}}\right)^{\text {" }} \mathrm{vs}$. time " $\mathrm{t}$ ". Similarly, $k_{2}\left(\mathrm{~g} \cdot \mathrm{mg}^{-1} \cdot \mathrm{h}^{-1}\right)$ is the pseudo 2 nd order rate constant obtained from the slope of the plot between " $\mathrm{t} / \mathrm{q}_{\mathrm{t}}$ " and " $\mathrm{t}$ ", whereas the value of " $\mathrm{q}_{\mathrm{e}}$ " is determined from intercept of the plot. Likewise, in Equation (5), $q_{t}$ shows the intra-particle diffusion model, $\mathrm{Ki}$ is the intra-particle diffusion rate constant $(\mathrm{g} / \mathrm{mg} \mathrm{min})$, and $\mathrm{c}$ is the intercept of the plot, which reproduces the boundary layer effect for the adsorption.

The following relations were used for calculation of $\Delta \mathrm{G}^{\circ}, \Delta \mathrm{H}^{\circ}$, and $\Delta \mathrm{S}^{\circ}$ [29].

$$
\begin{gathered}
\Delta \mathrm{G}^{\circ}=-\mathrm{RT} \ln \mathrm{K}_{\mathrm{D}} \\
\Delta \mathrm{H}^{\circ}=\mathrm{R} \frac{\mathrm{T}_{2} \mathrm{~T}_{1}}{\mathrm{~T}_{2}-\mathrm{T}_{1}} \ln \frac{\mathrm{K}_{2}}{\mathrm{~K}_{1}} \\
\Delta \mathrm{S}^{\circ}=\frac{\Delta \mathrm{H}^{\circ}-\Delta \mathrm{G}^{\circ}}{\mathrm{T}}
\end{gathered}
$$


The following relation was used to calculate Langmuir adsorption isotherm [30].

$$
\frac{\mathrm{C}_{\mathrm{e}}}{\mathrm{q}_{\mathrm{e}}}=\frac{1}{\mathrm{q}_{\mathrm{m}} \mathrm{k}_{\mathrm{b}}}+\frac{1}{\mathrm{q}_{\mathrm{m}} \mathrm{C}_{\mathrm{e}}}
$$

where, $C_{e}$ is the final concentration of $C r$ in the wastewater in $(\mathrm{mg} / \mathrm{L})$, and $\mathrm{q}_{\mathrm{e}}$ is the amount of $\mathrm{Cr}$ ions adsorbed on the adsorbent in $(\mathrm{mg} / \mathrm{g})$. Likewise, $\mathrm{q}_{\mathrm{m}}$ is the maximum adsorption limit, and $\mathrm{K}_{\mathrm{b}}$ is Langmuir constant, which is related to energy. Another very important parameter, called dimensionless isolating component $\left(\mathrm{R}_{\mathrm{L}}\right)$, is calculated from Langmuir isotherm by applying the following expression [31].

$$
\mathrm{R}_{\mathrm{L}}=\frac{1}{1+\mathrm{k}_{\mathrm{b}} \mathrm{C}_{\mathrm{e}}}
$$

To study Freundlich adsorption isotherm, the following relation was used [32].

$$
\log q_{e}=\log K f+\frac{1}{n} \log C_{e}
$$

\section{Results and Discussion}

In the current research, the adsorption and recovery of Cr-VI from wastewater was studied using $\mathrm{M}-\mathrm{AC}$ as adsorbent. The M-AC was prepared from tire waste, and then characterized by various instrumental analysis. The adsorption of $\mathrm{Cr}$-VI from the model and wastewater was studied in batch mode experiments.

\subsection{Characterization of Adsorbent}

\subsubsection{FTIR Analysis}

Figure 1 presents the FTIR spectra of the AC (a) and M-AC (b). The infrared spectrum of AC exhibits two maxima at around $1610 \mathrm{~cm}^{-1}$ and $1730 \mathrm{~cm}^{-1}$. The first one can be assigned to the stretching vibrations of $\mathrm{C}=\mathrm{C}$ bonds in aromatic carbon rings and pyrone structures as also the band at $\sim 1545 \mathrm{~cm}^{-1}$. The second absorption band at $1610 \mathrm{~cm}^{-1}$ can be assigned to asymmetric stretching vibrations of $-\mathrm{COOH}$ carboxyl and $-\mathrm{COO}^{-}$carbonyl, and / or $-\mathrm{C}=\mathrm{O}$ ketone units. The band at $1350 \mathrm{~cm}^{-1}$ can be attributed to symmetric stretching vibrations of $\mathrm{COOH}$ groups, whereas the bands around $1200 \mathrm{~cm}^{-1}$ to asymmetric stretch of -C-C-C bridges in ketonic groups and/or to deformation vibrations of O-H in the carboxylic acid groups. Peaks positioned at $1137 \mathrm{~cm}^{-1}$ and $1055 \mathrm{~cm}^{-1}$ show $\mathrm{C}-\mathrm{O}$ ether and $\mathrm{Si}-\mathrm{O}$ moieties [33]. The band centered at $3450 \mathrm{~cm}^{-1}$ is assigned to the $\mathrm{O}-\mathrm{H}$ stretching modes of the - $\mathrm{COOH}$, and phenolic $\mathrm{OH}$ groups; the weak bands at 2920 and $2860 \mathrm{~cm}^{-1}$ are assigned to $\mathrm{CH}_{3}$ and $\mathrm{CH}_{2}$ stretching vibration modes. The FTIR spectrum of M-AC shows similar configurations as that of AC, however, an additional absorption appears between 620-750 $\mathrm{cm}^{-1}$, which attributes to Fe-O stretching vibrations of magnetic iron oxides [34]. 


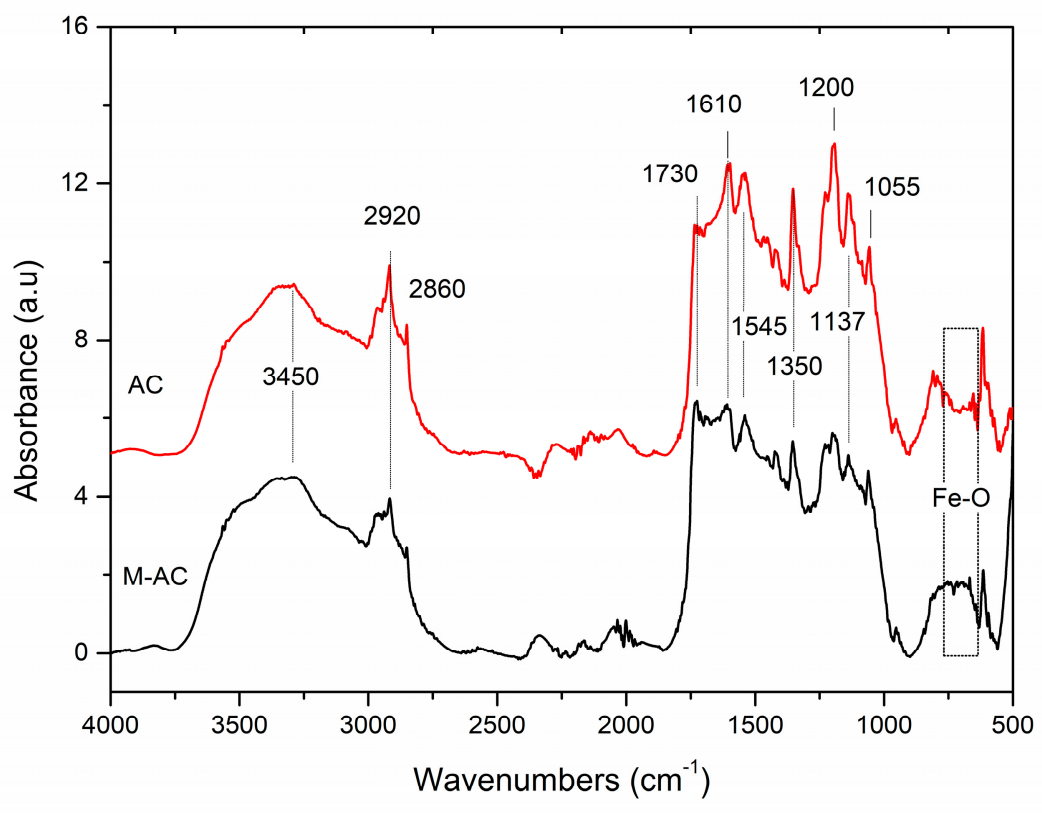

Figure 1. FTIR spectra of tire waste-derived activated carbon $(A C)$ and magnetic $A C(M-A C)$.

\subsubsection{XRD Analysis}

In the case of $A C$, the diffractogram (Figure 2) exhibits two characteristic broad reflection peaks centered at $2 \theta, 25^{\circ}$, and $43^{\circ}$, which can be attributed to the amorphous nature of activated carbon. On this background appear several sharp reflection peaks at $2 \theta 26.7,28.5,29.731 .8,36,39,7.6$, and $56.5^{\circ}$. These peaks may be assigned to quartz $\mathrm{SiO}_{2}$ (main peak at $26^{\circ}$; OCD: 96-900-0776) [20], calcite (main peak at 29.7\% OCD: 96-1010963), albite, $\mathrm{NaAlSi}_{3} \mathrm{O}_{8}\left(25.2,26,28.5\right.$ and $29.7^{\circ}$; OCD: 96-900-3703) and sphalerite, $\mathrm{ZnS}$ (28.5, 36, 47.6 and 56.5 ; OCD: 96-900-0108), which are assumed to be remains of the filler materials, or formed after pyrolysis [21]. The diffractogram of M-AC shows peaks at $2 \theta$ of $30,35.5,53.6,57.6$, and $62.8^{\circ}$, which indicate the crystalline patterns of magnetite $\left(\mathrm{Fe}_{3} \mathrm{O}_{4}\right.$; 96-900-2317) or maghemite ( $\gamma-\mathrm{Fe}_{2} \mathrm{O}_{3}$; OCD: 96-900-6317) [22], which indicates that both the magnetic oxides of iron, i.e., magnetite and maghemite, are impregnated on the surface of the AC.

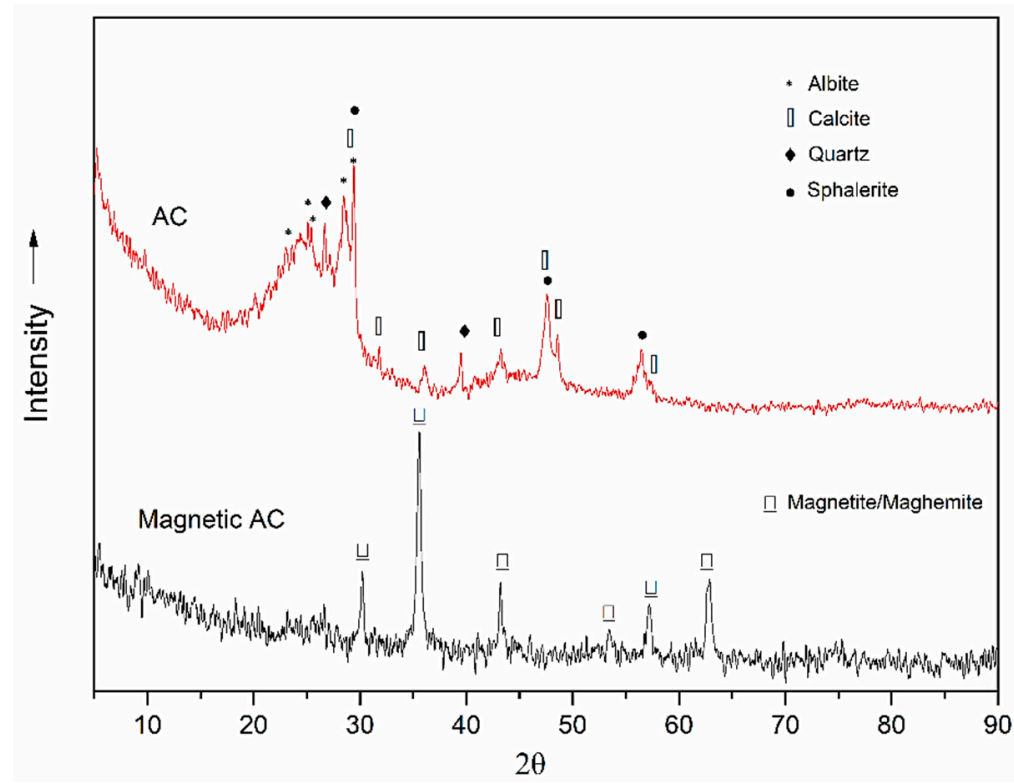

Figure 2. XRD patterns of tire waste-derived AC and M-AC. 


\subsubsection{FESEM Analysis}

The morphology of the AC and M-AC was investigated by FESEM microscopy. The FESEM micrographs of the AC and M-AC are indicated in Figure 3a-d. The micrographs of $A C$, indicated in lower and higher magnification (Figure $3 a, b$ ), show the highly porous and granular morphology of AC. The granules are stacked in layers, as evident from the FESEM micrograph, and the grain size is estimated to be in micrometer-sized particles. Some surface granules seem agglomerated, but deep caves and fissures can be seen. The M-AC (Figure 3c,d), also represents a similar morphology, however, the granules seem covered with a spongy layer of magnetic oxides. Additionally, more agglomeration can be observed on the surface, though the fissures size has been increased. Appearance of tire waste-derived $\mathrm{AC}$ as spherical nanometric particles is in agreement with literature reports [35].
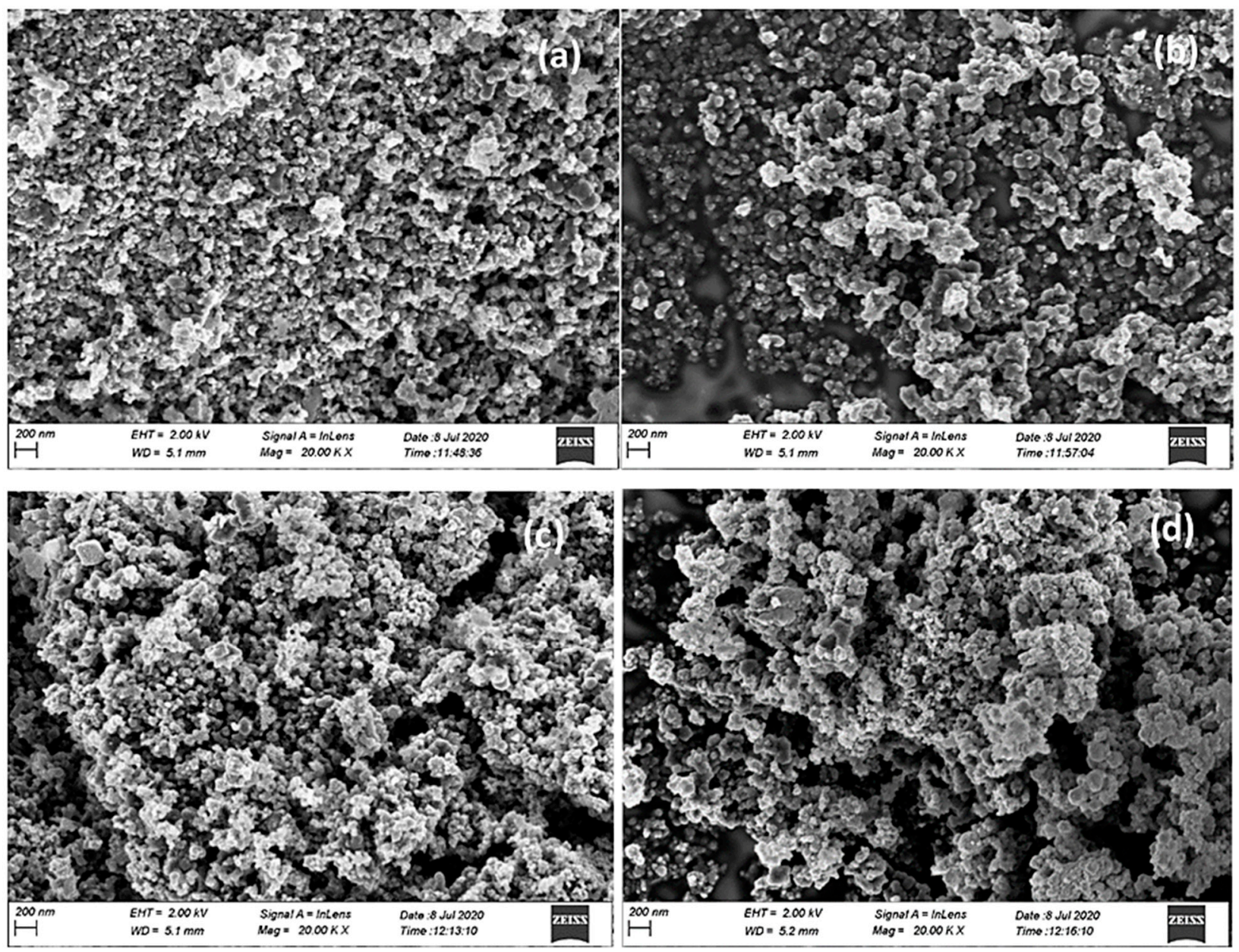

Figure 3. FE-SEM micrographs of tire waste-derived AC (a,b) and M-AC (c,d).

\subsubsection{EDX Analysis}

The elemental composition of the AC and M-AC was investigated by EDX analysis (Oxford Instruments, High Wycombe, United Kingdom). The EDX profiles of the samples are shown in Figure 4a,b, whereas the percentage of the various elements found in AC and $\mathrm{M}-\mathrm{AC}$ is given in Table 1 . In the case of $\mathrm{AC}$, the percentage of $\mathrm{C}$ and $\mathrm{O}$ was found to be 76 and $8 \%$, and the high quantity of $\mathrm{C}$ confirms the synthesis of activated carbon, whereas $\mathrm{O}$ may be present as surface functional groups of $\mathrm{AC}$ or as oxides. Additionally, some other elements, including $\mathrm{Na}(3 \%), \mathrm{Al}(1 \%), \mathrm{Si}(5 \%), \mathrm{S}(3 \%), \mathrm{K}(1 \%)$, and $\mathrm{Ca}(1 \%)$, which may be present as oxide impurities or as mineral clays which may be added to rubber as fillers, out of these sulfurs may be present in the tire waste in elemental form. Jha et. al. [36] has 
also reported the presence of various minerals, i.e., anorthite, spinel oxides, and quartz, etc., in the activated charcoal derived from tire waste char. In case of M-AC weight, percentages of $\mathrm{C}, \mathrm{O}$, and Fe were found to be 46,21 , and $30 \%$, respectively, which confirm the incorporation of magnetic iron oxides on $\mathrm{AC}$. The decrease in the concentration of other elements in the M-AC which were present in AC may be attributed to their extraction during magnetization and washing steps.
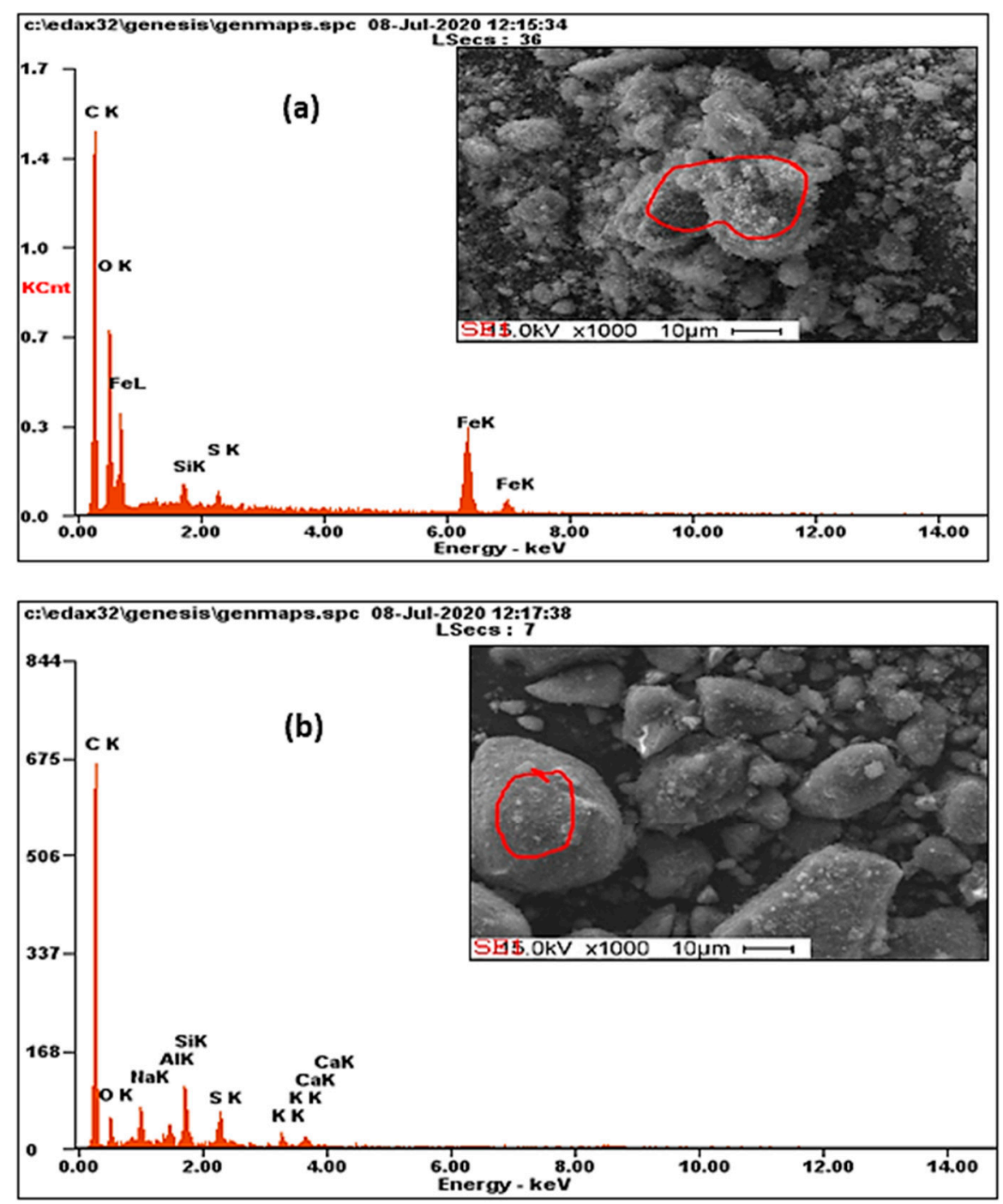

Figure 4. EDX profiles of tire waste-derived M-AC (a) and AC (b).

\subsection{Adsorption Experiments and Effect of Process Parameters}

The removal of $\mathrm{Cr}(\mathrm{VI})$ from model $\mathrm{Cr}$ solution was studied through batch mode adsorption using M-AC prepared from tire waste. The effects of various adsorption parameters on \% adsorption of $\mathrm{Cr}$ were investigated to optimize the conditions for maximum removal of $\mathrm{Cr}$ from the model $\mathrm{Cr}$ solution. 
Table 1. Elemental composition of tire waste-derived AC and M-AC.

\begin{tabular}{ccccc}
\hline \multirow{2}{*}{ Element } & \multicolumn{2}{c}{ AC } & \multicolumn{2}{c}{ Magnetic AC } \\
\cline { 2 - 5 } & $\mathbf{W t} \%$ & $\mathbf{A t} \%$ & $\mathbf{W t} \%$ & At\% \\
\hline $\mathrm{C}$ & 75.98 & 85.53 & 45.81 & 66.05 \\
\hline $\mathrm{O}$ & 08.63 & 07.30 & 21.43 & 23.20 \\
\hline $\mathrm{Na}$ & 03.08 & 01.81 & - & - \\
\hline $\mathrm{Al}$ & 01.41 & 00.71 & 01.25 & 00.77 \\
\hline $\mathrm{Si}$ & 04.94 & 02.38 & 00.89 & 00.48 \\
\hline $\mathrm{S}$ & 03.08 & 01.30 & - & - \\
\hline $\mathrm{K}$ & 01.44 & 00.50 & - & - \\
\hline $\mathrm{Ca}$ & 01.44 & 00.48 & 30.62 & 09.50 \\
\hline $\mathrm{Fe}$ & - & - &
\end{tabular}

Adsorption of $\mathrm{Cr}$ (VI) over M-AC was studied under a $\mathrm{pH}$ range of 2 to 9 , results are displayed in Figure $5 \mathrm{a}$, and the results show that maximum adsorption of about $98 \%$ occurs at low $\mathrm{pH}$, i.e., $\mathrm{pH} 2$, whereas with increasing the $\mathrm{pH}$ of the media, the \% adsorption of $\mathrm{Cr}$ declines. Since at low $\mathrm{pH}$ the adsorbent surface remains protonated, hence the anionic Cr species are adsorbed on the surface through electrostatic interaction [37]. It has been shown that in an aqueous medium, $\mathrm{Cr}$ may exist in different ionic forms such as chromate $\left(\mathrm{CrO}_{4}{ }^{-2}\right)$, dichromate $\left(\mathrm{Cr}_{2} \mathrm{O}_{7}^{-}\right)$, and hydrogen chromate $\left(\mathrm{HCrO}_{4}^{-}\right)$, which primarily depend upon the $\mathrm{pH}$ of the medium [38]. Generally, under acidic medium, the predominant oxy anionic $\mathrm{Cr}$ species are $\mathrm{HCrO}_{4}^{-}$and $\mathrm{Cr}_{2} \mathrm{O}_{7}^{-2}$ ions, whereas under basic medium, the $\mathrm{CrO}_{4}{ }^{-2}$ is more stable [39]. As $\mathrm{CrO}_{4}{ }^{-2}$ ion carries two negative charges, hence it requires two cationic sites for adsorption on the surface of the adsorbent, whereas $\mathrm{HCrO}_{4}{ }^{-}$or $\mathrm{Cr}_{2} \mathrm{O}_{7}{ }^{-}$ions carry one negative charge and therefore each need a single cationic site for adsorption [40], this means two fold number of $\mathrm{HCrO}_{4}{ }^{-}$or $\mathrm{Cr}_{2} \mathrm{O}_{7}{ }^{-}$ions can be adsorbed on the same number of cationic sites as compared to that of $\mathrm{CrO}^{-2}$ ions. Thus, under acidic conditions, more $\mathrm{Cr}$ can be adsorbed over the adsorbent surface because in acidic medium, $\mathrm{Cr}$ predominantly exists as $\mathrm{HCrO}_{4}{ }^{-}$or $\mathrm{Cr}_{2} \mathrm{O}_{7}{ }^{-}$ions, while requiring single cationic site, a large number of these ions will be adsorbed on a smaller unit surface area of the adsorbent. Moreover, at low $\mathrm{pH}$, competitive adsorption of $\mathrm{OH}^{-1}$ ions also declines the adsorption of Cr anionic species [41].

Adsorption efficiency of M-AC was also studied under different adsorbent doses ranging from 40 to $200 \mathrm{mg} / 10 \mathrm{~mL}$, and results shown in Figure $5 \mathrm{~b}$ indicate that adsorption of $\mathrm{Cr}(\mathrm{VI})$ increases with the increasing the adsorbent dose, and maximum adsorption of $94.5 \pm 1$ is attained by using a $100 \mathrm{mg} / 10 \mathrm{~mL}$ dose of M-AC, however, no further increase in adsorption occurs with the increasing of the adsorbent dose. Since a higher adsorbent dose offer more adsorption sites on the adsorbent surface, therefore the adsorption activity increased with the increasing adsorbent dose [42]. These results agree with literature reports, where different types of adsorbents have also been shown to attain maximum adsorption of $\mathrm{Cr}(\mathrm{VI})$ at an optimum dose of $100 \mathrm{mg}[13,43]$. 

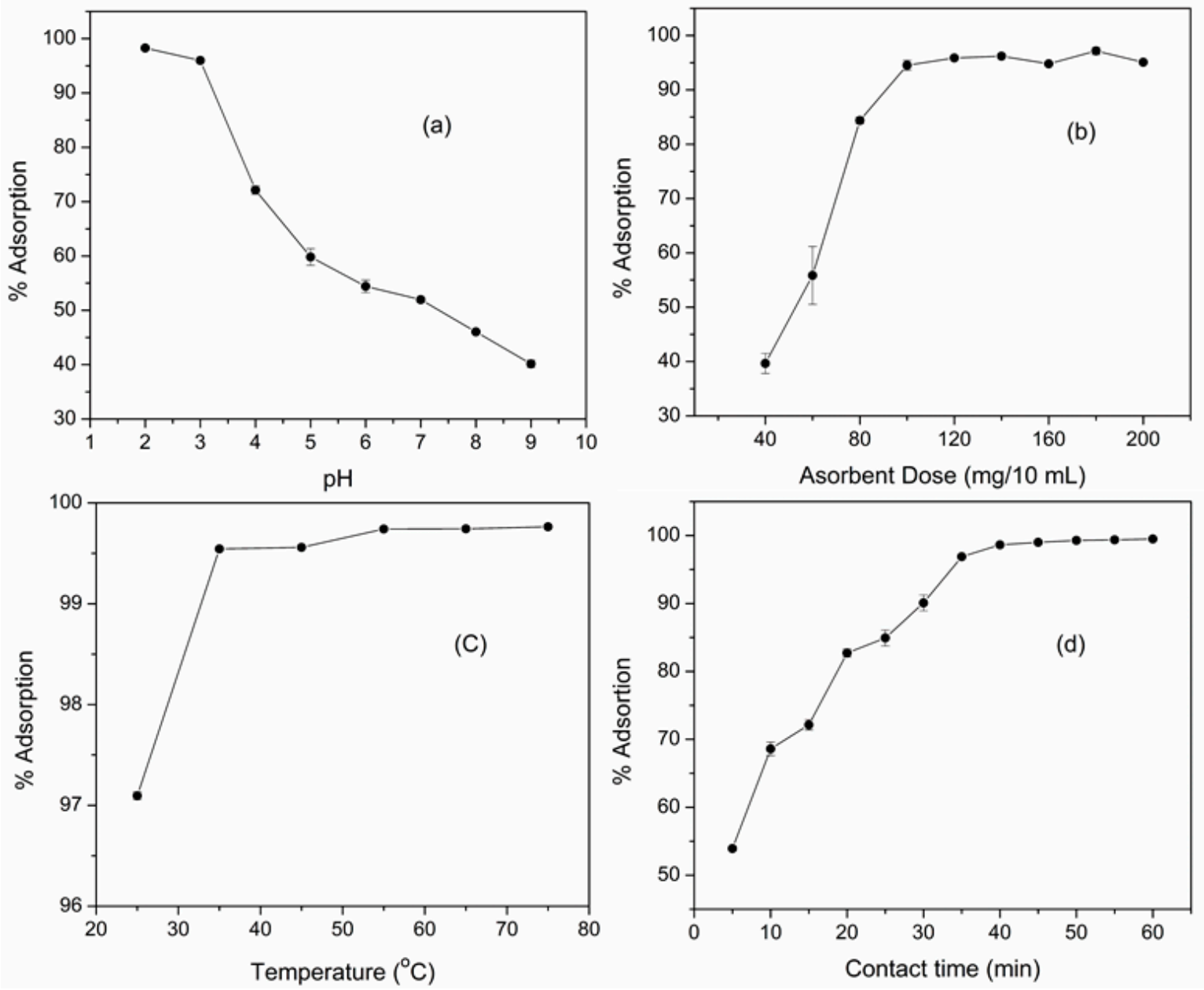

Figure 5. Effect of $\mathrm{pH}(\mathbf{a})$, adsorbent dose (b), temperature (c) and contact time (d) on the adsorption of Cr (VI) over M-AC.

The effect of temperature on adsorption of $\mathrm{Cr}$ (VI) between the temperature range of $25-75{ }^{\circ} \mathrm{C}$ has been shown in Figure $5 \mathrm{c}$. The data reveals that the adsorption abruptly increases with increasing temperature up to $35^{\circ} \mathrm{C}$, beyond which the adsorption activity almost remains constant. This may be attributed to the increase in the diffusion rate of the metal ion with rise in temperature [44]. Similarly, the effect of contact time on the adsorption activity was studied, which indicated that the adsorption of $\mathrm{Cr}$ (VI) over M-AC increased with the increase in contact time (Figure 5d). Equilibrium is attained in $30 \mathrm{~min}$, and with further increase in contact time, the adsorption activity stays constant.

It may be concluded from the above discussion that the optimum conditions for the maximum adsorption of $\mathrm{Cr}(\mathrm{VI})$ ions (99.5\%) over M-AC are; $\mathrm{pH} 2$, a sample volume of $10 \mathrm{~mL}$, an adsorbent dose of $100 \mathrm{mg} / 10 \mathrm{~mL}, 35^{\circ} \mathrm{C}$ temperature, and a contact time of $30 \mathrm{~min}$.

\subsection{Kinetic Study}

The effect of temperature on the $\mathrm{Cr}(\mathrm{VI})$ adsorption over M-AC has been described above, which revealed that with increasing temperature, the adsorption rate increases, and equilibrium adsorption is establish at $35^{\circ} \mathrm{C}$, as further increasing in the temperature causes no increase in adsorption of $\mathrm{Cr}$. A better description of adsorption rate can be explained by the interpretation of the adsorption data using various kinetics models.

Table 2 shows the values of different kinetic parameters. It can be observed from the Figure $6 a, b$ that the pseudo 2 nd order model gives straight line with higher $\mathrm{R}^{2}$ value (0.99) than that of the pseudo 1st order kinetic model (0.97). Similarly, the experimental value of $\mathrm{q}_{\mathrm{e}}$ has been found to be $49.314 \mathrm{mg} \cdot \mathrm{g}^{-1}$ (Table 2), which is more close to " $\mathrm{q}$ " calculated 
by the pseudo 2nd order model $\left(58.82 \mathrm{mg} \cdot \mathrm{g}^{-1}\right)$ as compared to that of the pseudo 1st order kinetic model $\left(30.63 \mathrm{mg} \cdot \mathrm{g}^{-1}\right)$. These results conclude that the adsorption of $\mathrm{Cr}$ (VI) over M-AC is in better agreement with the pseudo 2nd order kinetic model. Similarly, the intra-particle diffusion gives a linear plot with high $R^{2}$ value $(0.97)$, which means that the adsorption data agrees closely with the intra-particle diffusion model as shown in Figure 6c.

Table 2. Kinetic parameter of the adsorption of $\mathrm{Cr}$ (VI) on the surface of (MNPs-AC), pH 2, adsorbent dose $100 \mathrm{mg}$, and vortex time $35 \mathrm{~min}$

\begin{tabular}{|c|c|c|c|c|c|c|c|c|c|}
\hline \multirow{2}{*}{$\begin{array}{c}\text { Experimental } \\
\mathrm{q}_{\mathrm{e}} \\
\left(\mathrm{mg}^{-1} \mathrm{~g}^{-1}\right)\end{array}$} & \multicolumn{3}{|c|}{ Pseudo First Order } & \multicolumn{3}{|c|}{ Pseudo Second Order } & \multicolumn{3}{|c|}{ Intra-Particle Diffusion Model } \\
\hline & $\begin{array}{c}\mathrm{K}_{1} \\
\left(\min ^{-1}\right)\end{array}$ & $\begin{array}{c}q_{e} \\
\left(m g \cdot g^{-1}\right)\end{array}$ & $\mathbf{R}^{2}$ & $\begin{array}{c}\mathrm{K}_{2} \\
\left(\min ^{-1}\right)\end{array}$ & $\begin{array}{c}\mathrm{qe}_{\mathrm{e}} \\
\left(\mathrm{mg} \cdot \mathrm{g}^{-1}\right)\end{array}$ & $\mathbf{R}^{2}$ & $\begin{array}{c}\mathrm{K}_{\mathrm{i}} \\
(\mathrm{g} / \mathrm{mg} \cdot \min )\end{array}$ & C & $\mathbf{R}^{2}$ \\
\hline 49.314 & 0.064 & 30.63 & 0.97 & 0.0023 & 58.82 & 0.99 & 0.024 & 0.008 & 0.97 \\
\hline
\end{tabular}
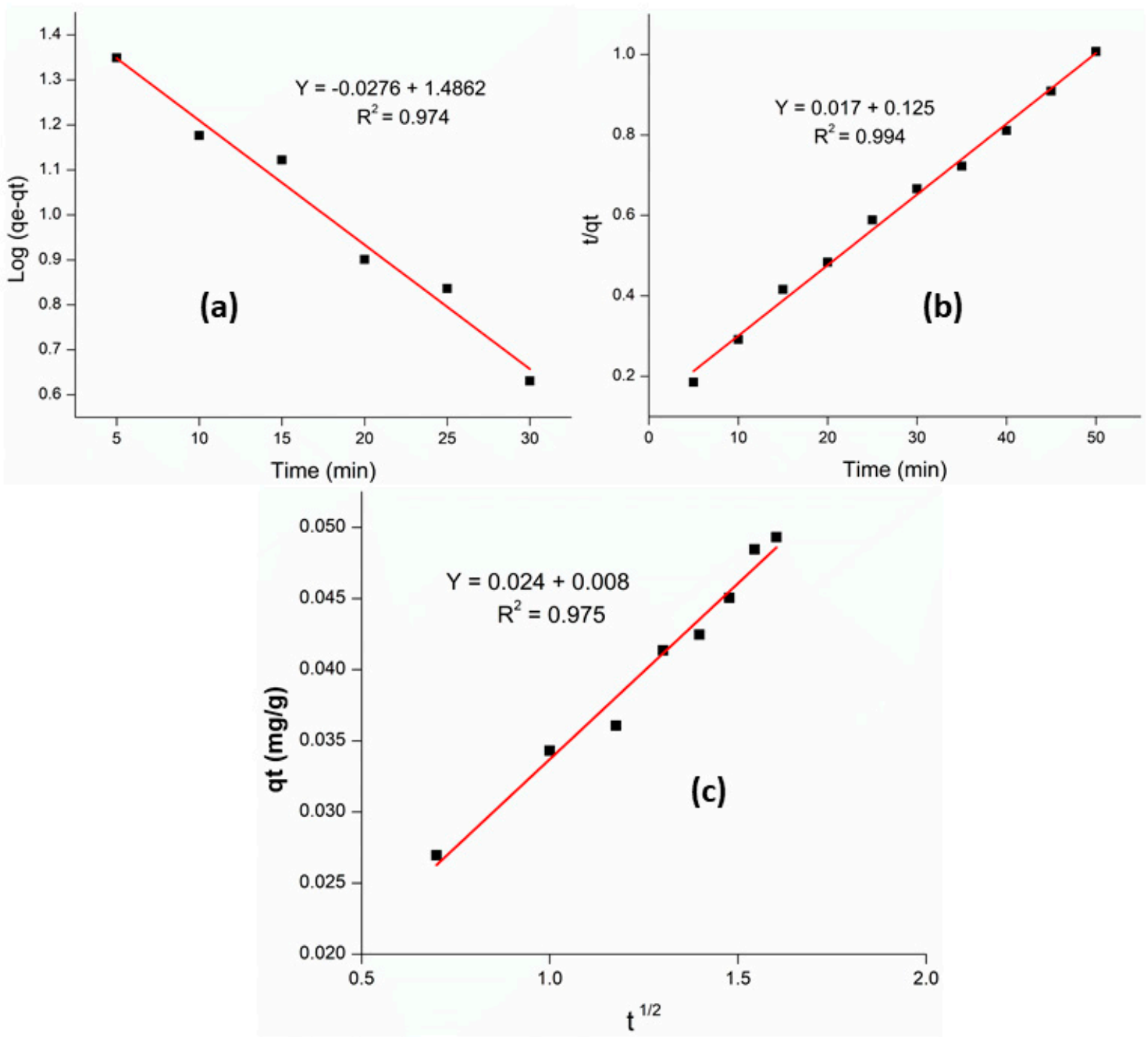

Figure 6. Pseudo 1st order (a), pseudo 2nd order (b), and intra particle diffusion (c) kinetic plot for adsorption of Cr (VI) over M-AC.

A number of research reports shows that $\mathrm{Cr}(\mathrm{VI})$ adsorption over different adsorbents such as M-AC derived from termite feces [45], acid treated saw dust, and saw dust car- 
bon [46] follow pseudo 2nd order kinetics. Nevertheless, several other studies show that the adsorption of $\mathrm{Cr}(\mathrm{VI})$ over the adsorbents, including $\mathrm{AC}$ obtained from olive stones [47] and graphene oxide [48], is in accordance with pseudo first order kinetics. This shows that the adsorption kinetics of $\mathrm{Cr}(\mathrm{VI})$ depend on the nature of the adsorbent material.

\subsection{Thermodynamic Studies}

Certain thermodynamic parameters provide important information about the nature of the adsorption phenomena and energy changes involved in it. Various important thermodynamic parameters, including Gibbs free energy $\left(\Delta \mathrm{G}^{\circ}\right)$, enthalpy $\left(\Delta \mathrm{H}^{\circ}\right)$, and entropy $\left(\Delta \mathrm{S}^{\circ}\right)$ were calculated from the adsorption data.

The results are given in Table 3, which indicates that at different temperatures, the values of $\Delta \mathrm{G}^{\circ}$ are found to be negative, and also the negative values of $\Delta \mathrm{G}^{\circ}$ increase with increasing the temperature. These results indicate that the adsorption of $\mathrm{Cr}(\mathrm{VI})$ on $\mathrm{M}-\mathrm{AC}$ is feasible and spontaneous in nature [49]. Additionally, the feasibility of adsorption increases with increases in temperature, and this is also in accordance with the effect of temperature on adsorption activity of the M-AC discussed in previous section. The value of enthalpy change $\left(\Delta \mathrm{H}^{\circ}\right)$ was found to have been calculated to be $26.09 \mathrm{KJ} \cdot \mathrm{mol}^{-1}$, which indicates that the adsorption process is endothermic in nature. It has been reported in literature that the adsorption system, having an $\Delta \mathrm{H}^{\circ}$ value between 2.1 to $20.9 \mathrm{KJ} \cdot \mathrm{mol}^{-1}$, the interaction of the adsorbate on the adsorbent surface will predominate through electrostatic attraction, which means the adsorption is physisorption, while if the value of $\Delta \mathrm{H}^{\circ}$ occurs in the range of 20.1 to $418.4 \mathrm{KJ} \cdot \mathrm{mol}^{-1}$, then transfer of charges may be involved between the adsorbate and adsorbent, driving the adsorption through chemisorption [50]. Since in the current scenario, the value of $\Delta \mathrm{H}^{\circ}$ is $26.09 \mathrm{KJ} \cdot \mathrm{mol}^{-1}$, i.e., above $20.9 \mathrm{KJ} \cdot \mathrm{mol}^{-1}$, hence the current adsorption system is chemisorption, which might involve the formation of a coordinate covalent bond between $\mathrm{Cr}(\mathrm{VI})$ ions and $\mathrm{M}-\mathrm{AC}$. Likewise, the value of change in entropy $\left(\Delta \mathrm{S}^{\circ}\right)$ is found to be $0.162 \mathrm{KJ} \cdot \mathrm{mol}^{-1} \mathrm{k}^{-1}$, which indicates the adsorption process is spontaneous and governed by entropy rather than enthalpy [51].

Table 3. Thermodynamic parameter for the adsorption of $\mathrm{Cr}$ (VI) over M-AC.

\begin{tabular}{|c|c|c|c|}
\hline Temperature (K) & $\Delta \mathrm{G}^{\circ}\left(\mathrm{KJ} \cdot \mathrm{mol}^{-1}\right)$ & $\Delta \mathrm{H}^{\circ}\left(\mathrm{KJ} \cdot \mathrm{mol}^{-1}\right)$ & $\Delta S^{\circ}\left(\mathrm{KJ} \cdot \mathrm{mol}^{-1} \mathrm{k}^{-1}\right)$ \\
\hline 298 & -21.58 & \multirow{6}{*}{26.069} & \multirow{6}{*}{0.162} \\
\hline 308 & -24.54 & & \\
\hline 318 & -25.43 & & \\
\hline 328 & -27.68 & & \\
\hline 338 & -28.56 & & \\
\hline 348 & -29.92 & & \\
\hline
\end{tabular}

\subsection{Adsorption Isotherms}

To study the adsorption process, the experimental data was fitted into Langmuir and Freundlich isotherms. The adsorption process greatly depends on the $R_{L}$ value. The $R_{L}$ value in the result was found to be 0.352 , which confirmed that the adsorption process is progressive and favorable. From the Langmuir isotherm graph, slope and intercept values were obtained, which verified the adsorption process may be favorable or unfavorable, reversible or irreversible, as shown in Table 4 . The graph was plotted between $C_{e} / q_{e}$ and $\mathrm{C}_{\mathrm{e}}$, as shown in Figure 7. The results indicated that the maximum adsorption capacity was found to $142.85 \mathrm{mg} / \mathrm{g}$, coefficient correlation factor $\left(\mathrm{R}^{2}\right)$ value was $(0.996)$ achieved, while Langmuir constant value was $\left(\mathrm{K}_{\mathrm{b}}=0.303\right)$ found, respectively. 
Table 4. Adsorption isotherm models, for adsorption $\mathrm{Cr}$ (VI) on M-AC composite.

\begin{tabular}{ccccccc}
\hline $\begin{array}{c}\text { Isotherm } \\
\text { Model }\end{array}$ & $\mathbf{R}^{\mathbf{2}}$ & $\mathbf{K f}$ & $\mathbf{1 / n}$ & $\mathbf{K}_{\mathbf{b}}$ & $\begin{array}{c}\mathbf{q}_{\mathbf{m}} \\
\mathbf{m g} \cdot \mathbf{g}^{-\mathbf{1}}\end{array}$ & $\mathbf{R}_{\mathbf{L}}$ \\
\hline $\begin{array}{c}\text { Langmuir } \\
\text { Isotherm }\end{array}$ & 0.996 & - & - & 0.303 & 142.85 & - \\
\hline $\begin{array}{c}\text { Freundlich } \\
\text { Isotherm }\end{array}$ & 0.828 & 0.242 & 0.168 & - & - & 0.352 \\
\hline
\end{tabular}
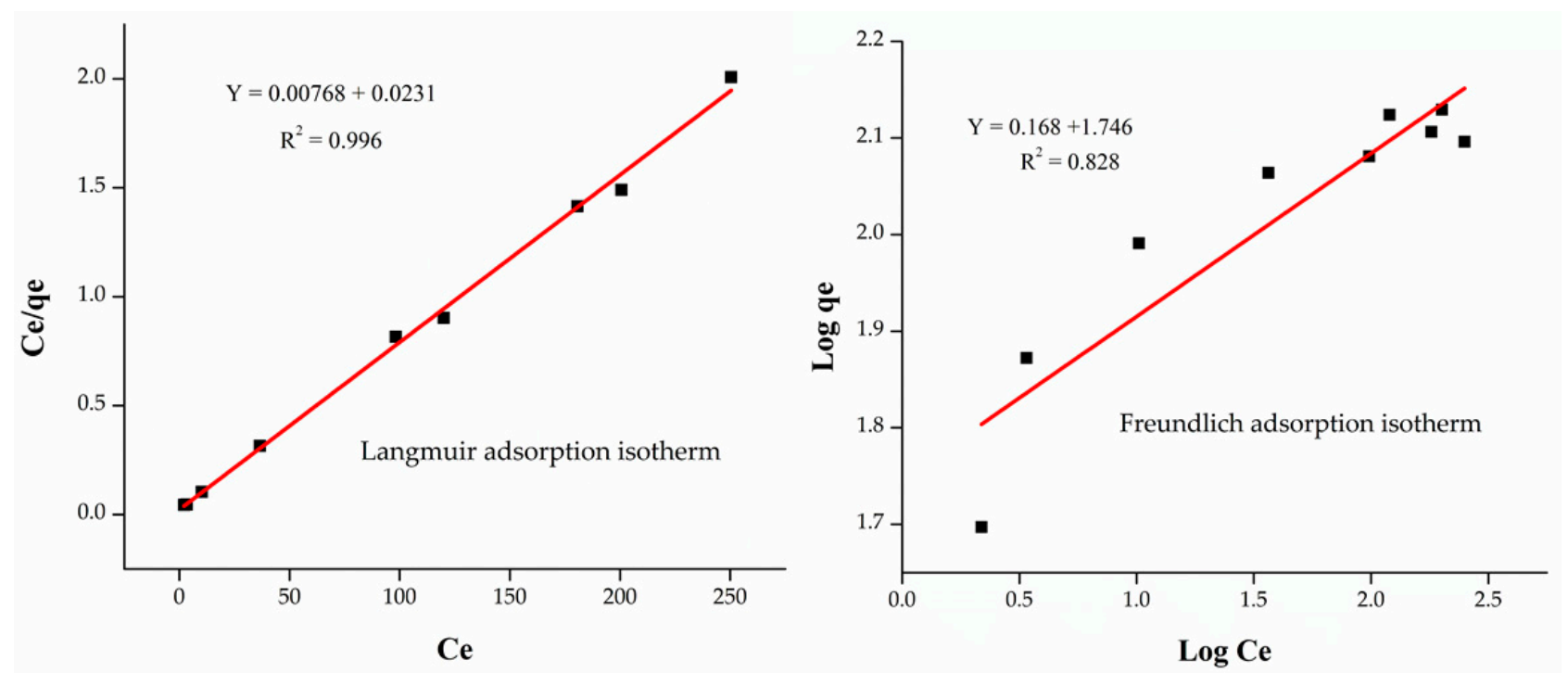

Figure 7. Plots of Langmuir and Freundlich adsorption isotherms for adsorption of Cr (VI) over M-AC.

The Freundlich adsorption isotherm gives information about whether the adsorption process is heterogeneous or not. The slope and intercept values are achieved with the Freundlich adsorption isotherm graph, as presented in Figure 7. In the Freundlich isotherm, $1 / \mathrm{n}$ value achieved 0.168 , which indicates that the adsorption process is applies over the whole range of concentrations [52].

The current result indicates that the $\mathrm{R}^{2}$ values for Langmuir and Freundlich adsorption isotherm were found to be (0.996) and (0.828), respectively, which means Langmuir adsorption isotherm fits more closely as compared to Freundlich. Likewise, the $\mathrm{R}_{\mathrm{L}}$ value was found to be 0.352 , which indicates the adsorption process is monolayer and favorable. Similarly, the $1 / \mathrm{n}$ value from the Freundlich isotherm was found to be 0.168 , which showed that the adsorption process is favorable at all possible concentrations.

\subsection{Recovery of $\mathrm{Cr}(\mathrm{VI})$ and Regeneration of Adsorbent}

In any adsorption process, the regeneration of the adsorption is a crucial step, which has a major economic impact on the industrial scale application of the process. The economy of the adsorption process depends upon how many times an adsorbent can be reused without losing its adsorption efficiency [53]. The recovery of $\mathrm{Cr}$ (VI) from the M-AC was carried out through desorption by leaching with various alkaline solutions. During the desorption process, the $\mathrm{Cr}(\mathrm{VI})$ loaded $\mathrm{M}-\mathrm{AC}$ was stirred with $1 \mathrm{M}$ and $2 \mathrm{M}$ solutions of $\mathrm{NaOH}$ and $\mathrm{NH}_{4} \mathrm{OH}$, respectively. $\mathrm{M}-\mathrm{AC}$ was recovered from the solution with the help of an external magnet, and the concentration of $\mathrm{Cr}(\mathrm{VI})$ in the alkaline solution was analyzed. Results given in Table 5 show that, $\mathrm{NaOH}$ solution was more effective than $\mathrm{NH}_{4} \mathrm{OH}$ in desorption of $\mathrm{Cr}(\mathrm{VI})$ from the surface of $\mathrm{M}-\mathrm{AC}$, and the highest $\mathrm{Cr}(\mathrm{VI})$ desorption of about $56 \%$ was attained by using $2 \mathrm{M} \mathrm{NaOH}$. Desorption of $\mathrm{Cr}(\mathrm{VI})$ from the surface adsorbent using basic solutions was critically reviewed. Many literature reports have also confirmed 
the high efficiency of $\mathrm{NaOH}$ solution in desorption of $\mathrm{Cr}(\mathrm{VI})$ from the surface of a variety of adsorbents [54,55].

Table 5. Influence of various eluents on the desorption of $\mathrm{Cr}(\mathrm{VI})$ ions from the adsorbent.

\begin{tabular}{cc}
\hline Leaching Solution & Cr (VI) Recovery (\%) \\
\hline $1 \mathrm{M} \mathrm{NaOH}$ & $45 \pm 2$ \\
$2 \mathrm{M} \mathrm{NaOH}$ & $56 \pm 1$ \\
$1 \mathrm{M} \mathrm{NH}_{4} \mathrm{OH}$ & $30 \pm 2$ \\
$2 \mathrm{M} \mathrm{NH} 4 \mathrm{OH}$ & $35 \pm 2$ \\
\hline
\end{tabular}

After desorption, the M-AC was regenerated by washing with $\mathrm{HCl}(0.1 \mathrm{M})$ and deionized water followed by vacuum drying at $60^{\circ} \mathrm{C}$. The regenerated $\mathrm{M}-\mathrm{AC}$ was further used for adsorption experiments using a fresh batch of $\mathrm{Cr}$ (VI) solution. The adsorption and desorption processes were repeated for several cycles. Results indicated that the $\mathrm{Cr}$ (VI) adsorption efficiency of M-AC was almost the same (95\%) for about ten repeated cycles. Additionally, the recovery or desorption efficiency of the M-AC also remained constant (about 51-55\%) for five consecutive cycles (Figure 8). This shows that the current adsorption system is not only helpful in the removal of $\mathrm{C}(\mathrm{VI})$, but also helps in the recovery of industrially important $\mathrm{Cr}$ metal from industrial effluents, which may be recycled and reused in other applications.

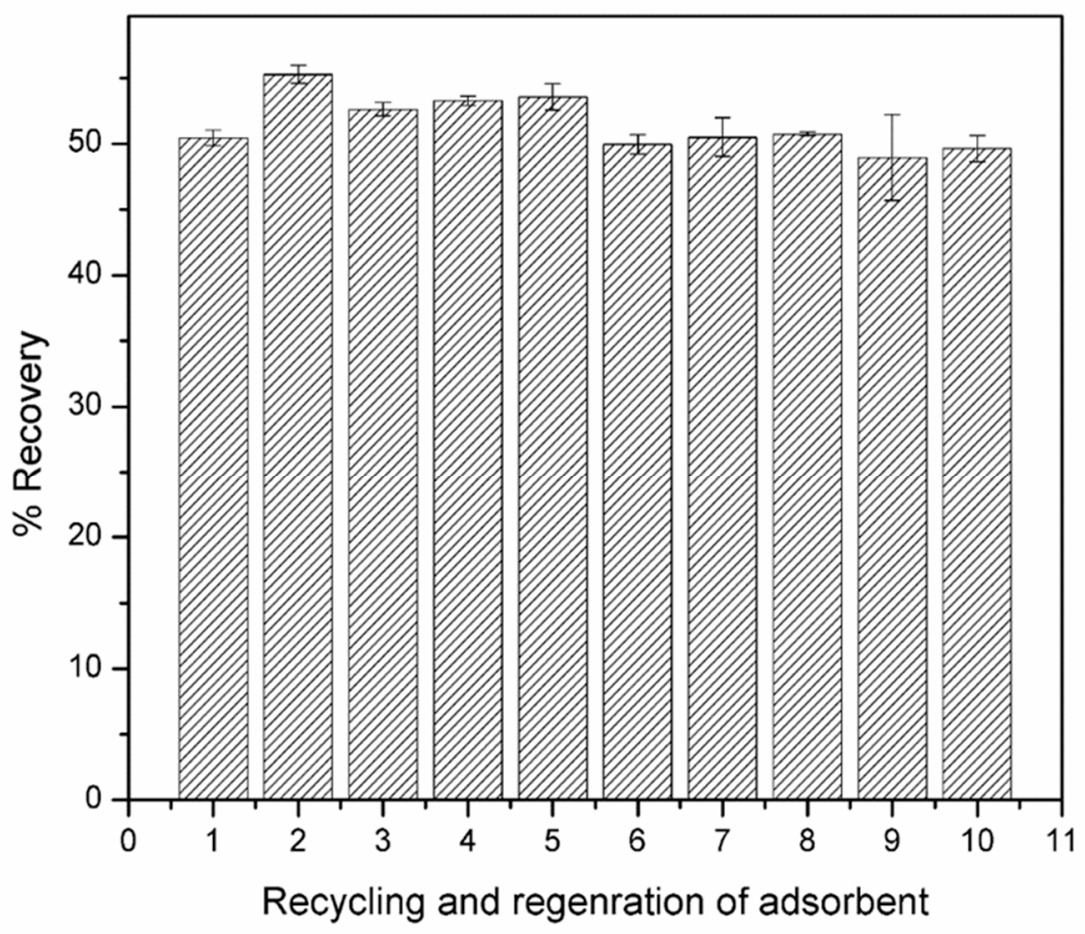

Figure 8. Recovery of $\mathrm{Cr}(\mathrm{VI})$ during repeated adsorption of desorption processes.

\subsection{Mechanism of Adsorption}

The mechanism of adsorption in the present study was due the interaction between hydrogen chromate $\left(\mathrm{HCrO}_{4}^{-}\right)$and the surface of $\mathrm{M}-\mathrm{AC}$. The main factor involved in the mechanism of adsorption of $\mathrm{Cr}(\mathrm{VI})$ is $\mathrm{pH}$. The maximum adsorption of $\mathrm{Cr}(\mathrm{VI})$ was found at $\mathrm{pH}$ 2. At this $\mathrm{pH}, \mathrm{Cr}_{2} \mathrm{O}_{7}{ }^{-2}$ is converted to $\mathrm{HCrO}_{4}{ }^{-}$species, as shown in the reaction [56].

$$
\mathrm{Cr}_{2} \mathrm{O}_{7}{ }^{-2}+\mathrm{H}_{2} \mathrm{O} \rightarrow 2 \mathrm{HCrO}_{4}
$$

The adsorptive capacity of magnetic composite was due to the active sites, present in both organic phases and inorganic, as well as new sites yield from the interaction of 
both phases. The adsorption of $\mathrm{HCrO}_{4}{ }^{-}$on active sites of organic and inorganic involves electrostatic interaction. The oxygen atom on the surface of the magnetic composite became protonated at $\mathrm{pH} 2$ to a great extent, which resulted in a strong electrostatic attraction between $\mathrm{HCrO}_{4}{ }^{-}$and positively charged adsorbent. At this condition, toxic $\mathrm{Cr}$ (VI) in tannery waste was adsorbed onto the surface of adsorbent (MNPs) by electrostatic attraction.

Studies have shown that iron oxide particles impart excellent adsorption properties due to their desirable surface characteristics [57]. In the present study, their impregnation on $\mathrm{AC}$ was intended for the ease of separation as adsorbent from the wastewater sample. Due to their low concentration over AC, their contribution towards adsorption has been considered very small. It is also probable that the electron donating surface functionalities of M-AC, as well as magnetic $\mathrm{Fe}^{+2}$, may cause the reduction of $\mathrm{Cr}$ (VI) to $\mathrm{Cr}$ (III), which may further be adsorbed over anionic site via ion exchange adsorption mechanism [58].

\subsection{Treatment of Tannery Wastewater}

Preliminary characterization of the tannery wastewater sample is presented in Table 6. Results show that the $\mathrm{pH}$, concentration of $\mathrm{Cr}$, chemical oxygen demand (COD), and suspended solids in tannery wastewater were 3.17, $1640 \mathrm{mg} / \mathrm{L}, 1130 \mathrm{mg} / \mathrm{L}$, and $960 \mathrm{mg} / \mathrm{L}$, respectively. According to Environmental Health Safety Guidelines (2009), the permissible limit for $\mathrm{pH}$ and COD in wastewater is $6-9$ and $150 \mathrm{mg} / \mathrm{L}$. Likewise, EPA guidelines limit the concentration of $\mathrm{Cr}$ in wastewater up to $200 \mathrm{ppm}$. These guidelines suggest that the tannery wastewater exceeds the permissible limits, especially in case of $\mathrm{Cr}$ concentration, therefore proper treatment is required to reduce the $\mathrm{Cr}$ concentration before disposal.

Table 6. Characteristics of tannery wastewater and removal of Cr.

\begin{tabular}{cc}
\hline Parametre & Values \\
\hline $\mathrm{pH}$ & 3.17 \\
COD & $1130 \mathrm{mg} / \mathrm{L}$ \\
Suspended solids & $960 \mathrm{mg} / \mathrm{L}$ \\
Concentration of Cr & $1640 \mathrm{mg} / \mathrm{L}$ \\
Removal of Cr through adsorption & $97 \%$ \\
\hline
\end{tabular}

The adsorption of $\mathrm{Cr}$ from tannery wastewater was investigated over M-AC under optimized conditions. Results presented in Table 6 display that about $97 \% \mathrm{Cr}$ was removed from tannery wastewater during adsorption. This shows that the magnetic AC (M-AC) also performed well in case of tannery wastewater like the model $\mathrm{Cr}$ solution. Hence, the adsorbent can be used on an industrial scale for treatment of tannery wastewater.

\subsection{Comparison of Adsorption Efficiency}

A variety of activated carbon-based adsorbents derived from low-cost carbonaceous waste materials have been used for adsorption of $\mathrm{Cr}(\mathrm{VI})$. These include various biomass materials and activated carbon derived from different biomass wastes such as olive stones, coconut shells, sugar wastes, pine leaves, saw dust, cactus leaves, etc. A summary of the comparative adsorption efficiencies of such adsorbents reported for removal of $\mathrm{Cr}$ (VI) ions with that of M-AC used in the current study has given in Table 7. It is clear from the comparison data that the M-AC offers high $\mathrm{Cr}(\mathrm{VI})$ adsorption efficiency under mild conditions and short contact time compare to the reported adsorbents. 
Table 7. Comparison of $\mathrm{Cr}$ (VI) adsorption efficiencies of various low-cost adsorbents.

\begin{tabular}{|c|c|c|c|}
\hline Adsorbent Materials & Experimental Conditions & Adsorption Capacity & Reference \\
\hline $\begin{array}{l}\text { Acid activated Carbon } \\
\text { derived from olive stones }\end{array}$ & $\begin{array}{c}\mathrm{pH} 1.5, \mathrm{Cr} \text { conc. in water } 4-50 \\
\mathrm{mg} / \mathrm{L}, \text { Adsorbent dose } 0.3 \mathrm{~g}\end{array}$ & $71 \mathrm{mg} / \mathrm{g}$ & [47] \\
\hline $\begin{array}{c}\text { Coconut shell charcoal (CSC) } \\
\text { and commercial activated } \\
\text { carbon (CAC) }\end{array}$ & Cr conc. $5,10,20$, and $25 \mathrm{mg} / \mathrm{L}$ & $\mathrm{CAC}$ at $4.7 \mathrm{mg} / \mathrm{g} \& \mathrm{CSC}$ at $5 \mathrm{mg} / \mathrm{L}$ & [59] \\
\hline $\begin{array}{l}\text { Wool, sawdust, pine needles, } \\
\text { almond shells, cactus leaves, } \\
\text { and charcoal }\end{array}$ & $\begin{array}{l}\text { Cr conc. } 20,100,200,300,400,500 \\
\text { and } 1000 \mathrm{mg} \mathrm{l}^{-1}, \\
\text { Adsorbent conc. } 16 \mathrm{~g} \mathrm{l}^{-1} \text { at } 30^{\circ} \mathrm{C}\end{array}$ & $81 \%$ out of $100 \mathrm{ppm} \mathrm{Cr}(\mathrm{VI})$ & {$[60]$} \\
\hline Green coconut shell & $\begin{array}{c}\text { Cr conc. } 10-100 \mathrm{mg} / \mathrm{g}, \mathrm{T} \text { range } \\
10-80^{\circ} \mathrm{C}\end{array}$ & $\begin{array}{c}22.9 \mathrm{mg} / \mathrm{g} \\
(90 \% \text { for } 10 \mathrm{mg} / \mathrm{L})\end{array}$ & {$[61]$} \\
\hline $\begin{array}{l}\text { Activated carbon }(\mathrm{C} 1, \mathrm{C} 2, \mathrm{C} 3) \\
\text { from industrial sugar waste }\end{array}$ & $\begin{array}{c}\mathrm{pH} 5-6, \mathrm{~T} 28^{\circ} \mathrm{C}, \mathrm{Cr} \text { conc. } 0.15 \text { and } \\
0.7 \mathrm{mg} / \mathrm{L}\end{array}$ & C1 98.86, C2 98.6 and C3 93\% & {$[62]$} \\
\hline $\begin{array}{c}\text { Activated carbon }(1), \\
\text { calcinated egg shells }(2), \\
\text { wheat bran (3), modified } \\
\text { wheat bran }(4)\end{array}$ & $\mathrm{Cr}$ conc. $10 \mathrm{mg} / \mathrm{L}, \mathrm{rpm}-180, \mathrm{~T} 35^{\circ} \mathrm{C}$ & $\begin{array}{c}98.75 \%(1), 64 \%(2), 75.89 \%(3) \\
96.96 \%(4)\end{array}$ & [63] \\
\hline $\begin{array}{l}\text { Silver impregnated groundnut } \\
\text { husk (1), activated carbon } \\
\text { from groundnut husk (2) }\end{array}$ & pH 1-3, Cr conc. $0.5 \mathrm{~g} / 100 \mathrm{~mL}$ & 11.4 mg/g (1), 7.0104 mg/g (2) & {$[64]$} \\
\hline $\begin{array}{l}\text { Inexpensive carbohydrates } \\
\text { derived supramolecular gels }\end{array}$ & $\begin{array}{c}\mathrm{pH} 7.4,250 \mathrm{mg} \text { or } 20 \mathrm{mg} \text { of gel at } 5 \\
\mathrm{wt} \% \text { in } 10 \text { or } 20 \mathrm{~mL} \text { Cr solutions }\end{array}$ & $\begin{array}{c}598 \mathrm{mg} / \mathrm{g} \\
(97 \% \text { in } 24 \mathrm{~h})\end{array}$ & [65] \\
\hline $\begin{array}{l}\text { Porous activated carbon from } \\
\text { Camellia oleifera seed }\end{array}$ & pH 2-8, Cr conc. $30 \mathrm{mg} \mathrm{L}^{-1}, \mathrm{~T} 25^{\circ} \mathrm{C}$ & $307.3 \mathrm{mg} / \mathrm{g}$ & {$[66]$} \\
\hline $\begin{array}{c}\text { Carbon nanocomposite from } \\
\text { natural diatomite }\end{array}$ & $\begin{array}{c}\mathrm{pH} 1, \mathrm{Cr} \text { conc. } 50-300 \mathrm{mg} / \mathrm{L}, \mathrm{T} \\
298.15 \mathrm{~K}\end{array}$ & $142.9 \mathrm{mg} / \mathrm{g}$ & [67] \\
\hline $\begin{array}{l}\text { Magnetic activated carbon } \\
(\mathrm{M}-\mathrm{AC}) \text { from tires waste }\end{array}$ & $\begin{array}{c}\mathrm{pH} 2,35{ }^{\circ} \mathrm{C}, 40 \mathrm{~min}, 100 \mathrm{mg} \\
\text { adsorbent }\end{array}$ & $49.3 \mathrm{mg} / \mathrm{g}$ & Current study \\
\hline
\end{tabular}

\section{Conclusions}

A well organized and novel adsorbent magnetic activated carbon (MNPs-AC) composite was synthesized and used as an adsorbent for adsorption of $\mathrm{Cr}(\mathrm{VI})$ ions from tannery wastewater. The composite material was analyzed by FTIR, XRD, and SEM. The FTIR analysis confirmed the successful synthesis of M-AC. Whereas, SEM analysis shows surface morphology of (MNPs-AC) composite, indicating a rough surface, MNPs are uniformly distributed on the surface, which offer a large exposed surface area for the adsorption of metal ions. During the batch study, an external magnetic field was used to separate the adsorbent from sample solution. At optimum conditions, (99.32 $\pm 2 \%$ ) adsorption of $\mathrm{Cr}$ (VI) ions was found at $\mathrm{pH} 2$, adsorbent dose $100 \mathrm{mg}$, sample volume $10 \mathrm{~mL}$, vortex time $30 \mathrm{~min}$. The adsorption of $\mathrm{Cr}(\mathrm{VI})$ adsorbent composite was found to be pseudo second order and endothermic in nature. The adsorbent showed high efficiency for ten cycles of uses, after regeneration. The $\mathrm{Cr}(\mathrm{VI})$ ion was successfully desorbed (56 $\pm 1 \%$ ) from the surface of adsorbent by using $20 \mathrm{~mL}$ of $2 \mathrm{M} \mathrm{NaOH}$ solution.

Author Contributions: W.A., original concept and initial draft of the paper, R.U., S.Q., materials synthesis, adsorption, and analysis of experiments, R.I., M.A.K., C.E.S., G.K., processing, structural characterizations, and data analysis, B.M.J., supervised and coordinated the experimental work, G.K., R.I., funding acquisition. All authors have read and agreed to the published version of the manuscript.

Funding: The authors would like to thank Fundamental Research Grant Scheme FP050-2019A, Malaysia-Thailand Joint Authority under grant number IF062-2019, and Kejuruteraan Kimia GPF078A- 
2018 from University of Malaya for providing the funds during the course of this study. This work was also supported by the National Priorities Research Program grant No. NPRP11S-1128-170042 from the Qatar National Research Fund (member of The Qatar Foundation), and co-financed by the European Union and Greek national funds through the Operational Program Competitiveness, Entrepreneurship and Innovation, under the call RESEARCH-CREATE-INNOVATE (2nd Cycle); acronym: SEMI-WEB; project code: T2EDK-02073.

Data Availability Statement: Data sharing not applicable, all the data created for this study is already displayed in the article.

Conflicts of Interest: The authors declare that there are no conflicts of interest regarding the publication of this manuscript.

\section{References}

1. Batool, A.; Saleh, T.A. Removal of toxic metals from wastewater in constructed wetlands as a green technology; catalyst role of substrates and chelators. Ecotoxicol. Environ. Saf. 2020, 189, 109924. [CrossRef] [PubMed]

2. Mella, B.; Puchana-Rosero, M.; Costa, D.; Gutterres, M. Utilization of tannery solid waste as an alternative biosorbent for acid dyes in wastewater treatment. J. Mol. Liq. 2017, 242, 137-145. [CrossRef]

3. Kokkinos, E.; Proskynitopoulou, V.; Zouboulis, A. Chromium and energy recovery from tannery wastewater treatment waste: Investigation of major mechanisms in the framework of circular economy. J. Environ. Chem. Eng. 2019, 7, 103307. [CrossRef]

4. Owlad, M.; Aroua, M.K.; Daud, W.A.W.; Baroutian, S. Removal of hexavalent chromium-contaminated water and wastewater: A review. Water Air Soil Pollut. 2009, 200, 59-77. [CrossRef]

5. Abdullah, N.; Yusof, N.; Lau, W.; Jaafar, J.; Ismail, A. Recent trends of heavy metal removal from water/wastewater by membrane technologies. J. Ind. Eng. Chem. 2019, 76, 17-38. [CrossRef]

6. Xiao, K.; Han, G.; Li, J.; Dan, Z.; Xu, F.; Jiang, L.; Duan, N. Evaluation of polyacrylic anion exchange resins on the removal of Cr (VI) from aqueous solutions. RSC Adv. 2016, 6, 5233-5239. [CrossRef]

7. Wójcik, G. Sorption and reduction of chromium ions by the chelating ion exchanger Diaion CR20. Physicochem. Probl. Miner. Process. 2019, 55, 1382-1393.

8. Park, D.; Yun, Y.-S.; Park, J.M. Studies on hexavalent chromium biosorption by chemically-treated biomass of Ecklonia sp. Chemosphere 2005, 60, 1356-1364. [CrossRef]

9. Shen, C.; Zhao, Y.; Li, W.; Yang, Y.; Liu, R.; Morgen, D. Global profile of heavy metals and semimetals adsorption using drinking water treatment residual. Chem. Eng. J. 2019, 372, 1019-1027. [CrossRef]

10. Kumari, M.; Pittman, C.U., Jr.; Mohan, D. Heavy metals [chromium (VI) and lead (II)] removal from water using mesoporous magnetite $\left(\mathrm{Fe}_{3} \mathrm{O}_{4}\right)$ nanospheres. J. Colloid Interface Sci. 2015, 442, 120-132. [CrossRef]

11. Adefa, T.; Tefera, M. Heavy Metal Accumulation and Health Risk Assessment in Moringa Oleifera from Awi Zone, Ethiopia. Chem. Afr. 2020, 3, 1073-1079. [CrossRef]

12. Geng, B.; Jin, Z.; Li, T.; Qi, X. Kinetics of hexavalent chromium removal from water by chitosan-Fe0 nanoparticles. Chemosphere 2009, 75, 825-830. [CrossRef] [PubMed]

13. Daneshvar, E.; Zarrinmehr, M.J.; Kousha, M.; Hashtjin, A.M.; Saratale, G.D.; Maiti, A.; Vithanage, M.; Bhatnagar, A. Hexavalent chromium removal from water by microalgal-based materials: Adsorption, desorption and recovery studies. Bioresour. Technol. 2019, 293, 122064. [CrossRef] [PubMed]

14. Zhitkovich, A. Chromium in drinking water: Sources, metabolism, and cancer risks. Chem. Res. Toxicol. 2011, 24, 1617-1629. [CrossRef] [PubMed]

15. Lal, S.; Singhal, A.; Kumari, P. Exploring carbonaceous nanomaterials for arsenic and chromium removal from wastewater. J. Water Process Eng. 2020, 36, 101276. [CrossRef]

16. Joshi, M.K.; Pant, H.R.; Liao, N.; Kim, J.H.; Kim, H.J.; Park, C.H.; Kim, C.S. In-situ deposition of silver- iron oxide nanoparticles on the surface of fly ash for water purification. J. Colloid Interface Sci. 2015, 453, 159-168. [CrossRef]

17. Yuan, X.; Wang, Y.; Wang, J.; Zhou, C.; Tang, Q.; Rao, X. Calcined graphene/MgAl-layered double hydroxides for enhanced Cr (VI) removal. Chem. Eng. J. 2013, 221, 204-213. [CrossRef]

18. Crini, G.; Lichtfouse, E.; Wilson, L.D.; Morin-Crini, N. Conventional and non-conventional adsorbents for wastewater treatment. Environ. Chem. Lett. 2019, 17, 195-213. [CrossRef]

19. Yahya, N.; Aziz, F.; Jamaludin, N.; Mutalib, M.; Ismail, A.; Salleh, W.; Jaafar, J.; Yusof, N.; Ludin, N. A review of integrated photocatalyst adsorbents for wastewater treatment. J. Environ. Chem. Eng. 2018, 6, 7411-7425. [CrossRef]

20. Abdullah, N.H.; Shameli, K.; Abdullah, E.C.; Abdullah, L.C. Solid matrices for fabrication of magnetic iron oxide nanocomposites: Synthesis, properties, and application for the adsorption of heavy metal ions and dyes. Compos. Part B Eng. 2019, 162, 538-568. [CrossRef]

21. Briton, B.G.H.; Duclaux, L.; Richardson, Y.; Yao, K.B.; Reinert, L.; Soneda, Y. Effectiveness of the dispersion of iron nanoparticles within micropores and mesopores of activated carbon for Rhodamine B removal in wastewater by the heterogeneous Fenton process. Appl. Water Sci. 2019, 9, 166. [CrossRef] 
22. Feizi, F.; Reguyal, F.; Antoniou, N.; Zabaniotou, A.; Sarmah, A.K. Environmental remediation in circular economy: End of life tyre magnetic pyrochars for adsorptive removal of pharmaceuticals from aqueous solution. Sci. Total Environ. 2020, 739, 139855. [CrossRef] [PubMed]

23. Shahrokhi-Shahraki, R.; Benally, C.; El-Din, M.G.; Park, J. High efficiency removal of heavy metals using tire-derived activated carbon vs commercial activated carbon: Insights into the adsorption mechanisms. Chemosphere 2021, 264, 128455. [CrossRef] [PubMed]

24. Adio, S.O.; Asif, M.; Mohammed, A.-R.I.; Baig, N.; Al-Arfaj, A.A.; Saleh, T.A. Poly (amidoxime) modified magnetic activated carbon for chromium and thallium adsorption: Statistical analysis and regeneration. Process Saf. Environ. Prot. 2019, 121, 254-262. [CrossRef]

25. Raji, C.; Anirudhan, T. Batch Cr (VI) removal by polyacrylamide-grafted sawdust: Kinetics and thermodynamics. Water Res. 1998, 32, 3772-3780. [CrossRef]

26. Lace, A.; Ryan, D.; Bowkett, M.; Cleary, J. Chromium Monitoring in Water by Colorimetry Using Optimised 1,5-Diphenylcarbazide Method. Int. J. Environ. Res. Public Health 2019, 16, 1803. [CrossRef]

27. Avila, M.; Burks, T.; Akhtar, F.; Göthelid, M.; Lansåker, P.C.; Toprak, M.S.; Muhammed, M.; Uheida, A. Surface functionalized nanofibers for the removal of chromium (VI) from aqueous solutions. Chem. Eng. J. 2014, 245, 201-209. [CrossRef]

28. Khan, M.; Yilmaz, E.; Sevinc, B.; Sahmetlioglu, E.; Shah, J.; Jan, M.R.; Soylak, M. Preparation and characterization of magnetic allylamine modified graphene oxide-poly (vinyl acetate-co-divinylbenzene) nanocomposite for vortex assisted magnetic solid phase extraction of some metal ions. Talanta 2016, 146, 130-137. [CrossRef]

29. Kandile, N.G.; Nasr, A.S. New hydrogels based on modified chitosan as metal biosorbent agents. Int. J. Biol. Macromol. 2014, 64, 328-333. [CrossRef]

30. Yousaf, I.; Rahman, U.; Mansoor, K. Solid phase extraction of Pb (II) and Cd (II) using reduced graphene oxide-polychloroprene impregnated with magnetic nanoparticle (MNPs-RGO-PCP). Desalin. Water Treat. 2018, 114, 232-241. [CrossRef]

31. Muhammad, A.; Shah, A.-U.-H.A.; Bilal, S.; Rahman, G. Basic Blue dye adsorption from water using Polyaniline/Magnetite $\left(\mathrm{Fe}_{3} \mathrm{O}_{4}\right)$ composites: Kinetic and thermodynamic aspects. Materials 2019, 12, 1764. [CrossRef] [PubMed]

32. Sharma, P.; Das, M.R. Removal of a cationic dye from aqueous solution using graphene oxide nanosheets: Investigation of adsorption parameters. J. Chem. Eng. Data 2013, 58, 151-158. [CrossRef]

33. Karmacharya, M.S.; Gupta, V.K.; Jha, V.K. Preparation of activated carbon from waste tire rubber for the active removal of Cr (VI) and Mn (II) ions from aqueous solution. Trans. Indian Ceram. Soc. 2016, 75, 234-241. [CrossRef]

34. Cazetta, A.L.; Pezoti, O.; Bedin, K.C.; Silva, T.L.; Paesano Junior, A.; Asefa, T.; Almeida, V.C. Magnetic Activated Carbon Derived from Biomass Waste by Concurrent Synthesis: Efficient Adsorbent for Toxic Dyes. ACS Sustain. Chem. Eng. 2016, 4, 1058-1068. [CrossRef]

35. Nunes, M.R.; Perez, G.M.; Loguercio, L.F.; Alves, E.W.; Carreño, N.L.V.; Martins, J.L.; Garcia, I.T.S. Active carbon preparation from treads of tire waste for dye removal in waste water. J. Braz. Chem. Soc. 2011, 22, 2027-2035. [CrossRef]

36. Jha, V.K.; Subedi, K. Preparation of activated charcoal adsorbent from waste tire. J. Nepal Chem. Soc. 2011, 27, 19-25. [CrossRef]

37. Dermentzis, K.; Christoforidis, A.; Valsamidou, E.; Lazaridou, A.; Kokkinos, N. Removal of hexavalent chromium from electroplating wastewater by electrocoagulation with iron electrodes. Glob. Nest J. 2011, 13, 412-418.

38. Lu, X.; Li, M.; Deng, H.; Lin, P.; Matsumoto, M.R.; Liu, X. Application of electrochemical depassivation in PRB systems to recovery Fe 0 reactivity. Front. Environ. Sci. Eng. 2016, 10, 4. [CrossRef]

39. Wang, J.; Pan, K.; He, Q.; Cao, B. Polyacrylonitrile/polypyrrole core/shell nanofiber mat for the removal of hexavalent chromium from aqueous solution. J. Hazard. Mater. 2013, 244, 121-129. [CrossRef]

40. Tran, T.K.; Leu, H.J.; Vu, T.Q.; Nguyen, M.T.; Pham, T.A.; Kiefer, R. Hydrogen production from the tannery wastewater treatment by using agriculture supports membrane/adsorbents electrochemical system. Int. J. Hydrog. Energy 2020, 45, 3699-3711. [CrossRef]

41. Song, Z.; Williams, C.; Edyvean, R. Treatment of tannery wastewater by chemical coagulation. Desalination 2004, 164, 249-259. [CrossRef]

42. Chun, L.; Hongzhang, C.; Zuohu, L. Adsorptive removal of Cr (VI) by Fe-modified steam exploded wheat straw. Process Biochem. 2004, 39, 541-545. [CrossRef]

43. Kozlowski, C.A.; Walkowiak, W. Removal of chromium (VI) from aqueous solutions by polymer inclusion membranes. Water Res. 2002, 36, 4870-4876. [CrossRef]

44. Hussain, S.; Gul, S.; Khan, S.; ur Rehman, H. Retention studies of chromium (VI) from aqueous solution on the surface of a novel carbonaceous material. Arab. J. Geosci. 2013, 6, 4547-4556. [CrossRef]

45. Demarchi, C.A.; Michel, B.S.; Nedelko, N.; Ślawska-Waniewska, A.; Dłużewski, P.; Kaleta, A.; Minikayev, R.; Strachowski, T.; Lipińska, L.; Dal Magro, J.; et al. Preparation, characterization, and application of magnetic activated carbon from termite feces for the adsorption of Cr(VI) from aqueous solutions. Powder Technol. 2019, 354, 432-441. [CrossRef]

46. Garg, V.; Gupta, R.; Kumar, R.; Gupta, R. Adsorption of chromium from aqueous solution on treated sawdust. Bioresour. Technol. 2004, 92, 79-81. [CrossRef]

47. Attia, A.; Khedr, S.; Elkholy, S. Adsorption of chromium ion (VI) by acid activated carbon. Braz. J. Chem. Eng. 2010, 27, 183-193. [CrossRef] 
48. Mondal, N.K.; Chakraborty, S. Adsorption of $\mathrm{Cr}(\mathrm{VI})$ from aqueous solution on graphene oxide (GO) prepared from graphite: Equilibrium, kinetic and thermodynamic studies. Appl. Water Sci. 2020, 10, 61. [CrossRef]

49. Ullah, R.; Ahmad, W.; Ahmad, I.; Khan, M.; Iqbal Khattak, M.; Hussain, F. Adsorption and recovery of hexavalent chromium from tannery wastewater over magnetic max phase composite. Sep. Sci. Technol. 2020, 1-14. [CrossRef]

50. Liu, H.; Zhang, F.; Peng, Z. Adsorption mechanism of Cr (VI) onto GO/PAMAMs composites. Sci. Rep. 2019, 9, 1-12. [CrossRef]

51. Shakoor, S.; Nasar, A. Adsorptive decontamination of synthetic wastewater containing crystal violet dye by employing Terminalia arjuna sawdust waste. Groundw. Sustain. Dev. 2018, 7, 30-38. [CrossRef]

52. Salem, M.A. The role of polyaniline salts in the removal of direct blue 78 from aqueous solution: A kinetic study. React. Funct. Polym. 2010, 70, 707-714. [CrossRef]

53. Hu, J.; Chen, G.; Lo, I.M. Removal and recovery of Cr (VI) from wastewater by maghemite nanoparticles. Water Res. 2005, 39, 4528-4536. [CrossRef] [PubMed]

54. Hu, B.; He, M.; Chen, B. Nanometer-sized materials for solid-phase extraction of trace elements. Anal. Bioanal. Chem. 2015, 407, 2685-2710. [CrossRef]

55. Vuong Hoan, N.T.; Anh Thu, N.T.; Duc, H.V.; Cuong, N.D.; Quang Khieu, D.; Vo, V. $\mathrm{Fe}_{3} \mathrm{O}_{4}$ /reduced graphene oxide nanocomposite: Synthesis and its application for toxic metal ion removal. J. Chem. 2016, 2016, 2418172. [CrossRef]

56. Amuda, O.; Ibrahim, A. Industrial wastewater treatment using natural material as adsorbent. Afr. J. Biotechnol. 2006, 5, $1483-1487$.

57. Jain, M.; Yadav, M.; Kohout, T.; Lahtinen, M.; Garg, V.K.; Sillanpää, M. Development of iron oxide/activated carbon nanoparticle composite for the removal of $\mathrm{Cr}(\mathrm{VI}), \mathrm{Cu}(\mathrm{II})$ and $\mathrm{Cd}(\mathrm{II})$ ions from aqueous solution. Water Resour. Ind. 2018, 20, 54-74. [CrossRef]

58. Valentín-Reyes, J.; García-Reyes, R.B.; García-González, A.; Soto-Regalado, E.; Cerino-Córdova, F. Adsorption mechanisms of hexavalent chromium from aqueous solutions on modified activated carbons. J. Environ. Manag. 2019, 236, 815-822. [CrossRef]

59. Kurniawan, T.; Babel, S. A research study on Cr (VI) removal from contaminated wastewater using low-cost adsorbents and commercial activated carbon. In Proceedings of the Second Int. Conf. on Energy Technology towards a Clean Environment (RCETE), Phuket, Thailand, 12-14 February 2003; pp. 1110-1117.

60. Dakiky, M.; Khamis, M.; Manassra, A.; Mer'Eb, M. Selective adsorption of chromium (VI) in industrial wastewater using low-cost abundantly available adsorbents. Adv. Environ. Res. 2002, 6, 533-540. [CrossRef]

61. Kumar, S.; Meikap, B. Removal of chromium (VI) from waste water by using adsorbent prepared from green coconut shell. Desalin. Water Treat. 2014, 52, 3122-3132. [CrossRef]

62. Fahim, N.; Barsoum, B.; Eid, A.; Khalil, M. Removal of chromium (III) from tannery wastewater using activated carbon from sugar industrial waste. J. Hazard. Mater. 2006, 136, 303-309. [CrossRef] [PubMed]

63. Renu, M.A.; Singh, K.; Upadhyaya, S.; Dohare, R. Removal of heavy metals from wastewater using modified agricultural adsorbents. Mater. Today Proc. 2017, 4, 10534-10538. [CrossRef]

64. Dubey, S.P.; Gopal, K. Adsorption of chromium (VI) on low cost adsorbents derived from agricultural waste material: A comparative study. J. Hazard. Mater. 2007, 145, 465-470. [CrossRef] [PubMed]

65. Rizzo, C.; Andrews, J.L.; Steed, J.W.; D'Anna, F. Carbohydrate-supramolecular gels: Adsorbents for chromium (VI) removal from wastewater. J. Colloid Interface Sci. 2019, 548, 184-196. [CrossRef]

66. Guo, H.; Bi, C.; Zeng, C.; Ma, W.; Yan, L.; Li, K.; Wei, K. Camellia oleifera seed shell carbon as an efficient renewable bio-adsorbent for the adsorption removal of hexavalent chromium and methylene blue from aqueous solution. J. Mol. Liq. 2018, 249, 629-636. [CrossRef]

67. Sun, Z.; Liu, B.; Li, M.; Li, C.; Zheng, S. Carboxyl-rich carbon nanocomposite based on natural diatomite as adsorbent for efficient removal of Cr (VI). J. Mater. Res. Technol. 2020, 9, 948-959. [CrossRef] 